TAPROBANICA, ISSN 1800-427X. August, 2014. Vol. 06, No. 02: pp. 110-131, pls. 12, 13.

(C) Research Center for Climate Change, University of Indonesia, Depok, Indonesia

\& Taprobanica Private Limited, Homagama, Sri Lanka

http://www.sljol.info/index.php/tapro

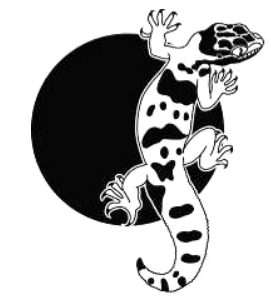

\title{
A COMPILATION AND ANALYSIS OF FOOD PLANTS UTILIZATION OF SRI LANKAN BUTTERFLY LARVAE (PAPILIONOIDEA)
}

Section Editors: Jeffrey Miller \& James L. Reveal $\quad$ Submitted: 08 Dec. 2013, Accepted: 15 Mar. 2014

\author{
H. D. Jayasinghe ${ }^{1,2}$, S. S. Rajapaksha ${ }^{1}$, C. de Alwis ${ }^{1}$
}

${ }^{1}$ Butterfly Conservation Society of Sri Lanka, 762/A, Yatihena, Malwana, Sri Lanka
${ }^{2}$ E-mail: himesh.jayasinghe1@ gmail.com

\begin{abstract}
Larval food plants (LFPs) of Sri Lankan butterflies are poorly documented in the historical literature and there is a great need to identify LFPs in conservation perspectives. Therefore, the current study was designed and carried out during the past decade. A list of LFPs for 207 butterfly species (Super family Papilionoidea) of Sri Lanka is presented based on local studies and includes 785 plant-butterfly combinations and 480 plant species. Many of these combinations are reported for the first time in Sri Lanka. The impact of introducing new plants on the dynamics of abundance and distribution of butterflies, the possibility of butterflies being pests on crops, and observations of LFPs of rare butterfly species, are discussed. This information is crucial for the conservation management of the butterfly fauna in Sri Lanka.
\end{abstract}

Key words: conservation, crops, larval food plants (LFPs), pests, plant-butterfly combination.

\section{Introduction}

Butterflies go through complete metamorphosis and have two stages of food consumtion. In the adult stage butterfly mandibles are developed into a tube-like proboscis facilitating feeding on liquids. In the adult stage butterflies are not limited to specific plant species for food and many species also feed on non-herbaceous materials such as bird droppings. The larval stage has chewing appendages, so their food type, vegetation, is completely different from the adult stage (d'Abrera, 1998; Kunte, 2000). Very rarely some butterfly larvae are carnivorous i.e., Spalgis epeus (Woodhouse,
1949). As all herbivorous insects show some degree of host selectivity (Bernays \& Chapman 1994), many butterfly larvae feed on a limited number of identical plant species (Wiklund, 1975), which is basically determined by the chemical composition of those plants (Kunte, 2000). Though they have a specialization on a set of closely related plants (Ehrlich \& Murphy, 1988; Ward \& Spalding, 1993), their preference of plants and different parts of plants could vary among genotypes and among individuals with different phenological and physiological conditions (Wiklund, 1984). The most common 
plant component which is consumed by larvae is immature leaves while some prefer mature leaves, flowers, fruits, seeds and roots. Behaviors and body structure of larvae are compatible with the plant component that they feed on. Caterpillars injest a majority of the nutrients required for growth and development into the adult stage, as well as chemicals required for the colors and defensive strategies in their adult stage (Boppré, 1984).

At present, Sri Lanka is inhabited by 245 butterfly species including 26 endemic species. (van der Pootern, 2012; Jayasinghe et al., 2013). Two new arrivals from other countries have been added to the list - Catopsilia scylla (van der Pootern \& van der Pootern, 2012a), Cephrenes trichopepla (van der Pootern \& van der Pootern, 2012d) and the presence of Spindasis greeni was confirmed recently (van der Pootern \& van der Pootern, 2012c). Moore (1880-1881) documented a small number of butterfly larval food plants (LFPs) in Sri Lanka, based on his local studies. Woodhouse (1949) enhanced this list based on the data given him by E. E. Green, Tunnard, Manders and Wiley. Although in his account early stages of 191 butterfly species have been documented, only 80 were based on Sri Lankan material while others were taken from Indian studies, which are not purely compatible to LFP preference and body color pattern of local butterfly larvae. Also, some plants were not identified to species and other plants have not been recorded in Sri Lanka. Recently van der Pootern \& van der Pootern (2011-2013) published more work on early stages of selected species including their larval food plants along with a comparison with historical studies.

The flora of Sri Lanka consists of 4,143 flowering plant species which some $25 \%$ are exotics and $20 \%$ represent endemics; this information is based on the series of "Revised hand book to the flora of Ceylon - vol I-XIV" (Senarathna, 2001). More species remain to be added to the Sri Lanka plant list according to recent studies (de Vlaas \& de Vlaas, 2008; Fernando \& Ormerod, 2008). Food of butterflies makes a significant role in determining their distribution, abundance and movement (Kunte, 2000) and the availability of LFPs is of prime importance for having a breeding population in a certain habitat (VaneWright, 1978). Identification of LFPs is valuable information for conservation management of butterflies. Some species are capable of adapting to novel LFPs to maintain a viable population even in manmade habitats, including certain species that turn out to be pests of crops. But highly food-specific butterfly caterpillars require the conservation of their special habitats including specific plants for their survival. The available data on LFPs of Sri Lankan butterflies is not sufficient for many butterfly species considered to be high among conservation priorities. The current study is focused on presenting an updated LFPs list of Sri Lankan butterflies based on both published and unpublished data on local material and eliminating Indian records published in local literature. Most of the plants in our revised-updated Sri Lanka list are recorded for the first time. It is our expectation that the publication of this list will stimulate further caterpillar foodplant studies, including preferences and geographic distributions.

\section{Materials and Methods}

This work is primarily based on ongoing studies initiated by the authors in 2002. Field studies were conducted throughout the island with limited access to northern and eastern regions. Observations on butterflies were carried out in all habitat types where butterflies are found, ranging from dense forests to urban home gardens. When female butterflies were observed searching for LFPs they were followed until they laid eggs. Also, suspected foodplants were searched thoroughly, especially when plants showed chewed leaves or the presence of caterpillar frass.

Eggs and larvae were collected and reared until maturity in captivity with repeated supplement of fresh plant materials on which they were found. Suitable materials such as sticks, leaves, bark, fruit shells, leaf litter and sand were provided for pupation. All the necessary data (e.g. color patterns of different instars; behaviours of larvae; durations of different instars and pupa; collected location, date and habitat; feeding materials) were recorded in field note books and if available, photographs were taken. The lab-rearing studies were carried out in Buththala $(6.771 \mathrm{~N}, 81.260 \mathrm{E})$, Wellawaya $(6.730 \mathrm{~N}, 81.099 \mathrm{E})$, Bandarawela $(6.830 \mathrm{~N}, \quad 80.988 \mathrm{E}), \quad$ Soragune $(6.747 \mathrm{~N}$, 80.893E), Katubedda $(6.797 \mathrm{~N}, 79.901 \mathrm{E})$ and Malwana $(6.968 \mathrm{~N}, 80.006 \mathrm{E})$. These locations 
covered the four main environmental conditions in which butterflies occur in Sri Lanka, namely low country wet zone, low country dry zone, intermediate zone, and hill country. The few butterfly species that are restricted to the northern region were reared at Wellawaya. Reared adults were released back into their original habitats.

Butterfly species were identified from the adult stage acquired either at the time of ovipositing or after eclosing following the lab-rearing study. Taxonomic authority followed that of d'Abrera (1998) and Woodhouse (1949). Nomenclature was used after van der Pootern, 2012 with a single correction (Kawahara, 2013). Detailed photographs of LFPs including leaves, flowers and fruits were taken with either Cannon 40 D, Cannon $60 \mathrm{D}$ or Cannon $7 \mathrm{D}$ fitted with Canon 100mm EF 2.8 Macro USM lens or Canon $100 \mathrm{~mm}$ EF 2.8L Macro IS USM lens. The photographs were compared with the descriptions of "Revised hand book to the flora of Ceylon - vol I-XIV" and "Illustrated field guide to the flowers of Sri Lanka vol 1 , vol 2 (unpublished) for identification.

All previously published data based on studies over the last ten years are also included in this compilation. Some published historical data have not been considered given that the relevance of those data had been discussed in great detail already (van der Pootern \& van der Pootern, 2011-2013). Unpublished data by other investigators are also included but only if verified by detailed photographs. In such cases plant species were identified by the authors. Information of authorships may be found on The Plant List (www.theplantlist.org) or on GRIN (www.ars-grin.gov). The families recognized here are based on the findings in APG-III (2009).

\section{Results and Discussion}

LFPs of 207 butterfly species (84\% of total species in Sri Lanka) are listed in this study with 785 plant-butterfly combinations. Spalgis epeus epeus larvae are feeding on mealy bugs (Woodhouse, 1949) and Spindasis greeni is assumed to feed on ant brood (van der Pootern \& van der Pootern, 2012c). LFPs of 36 Sri Lankan species are yet to be discovered including some common butterflies such as Appias albina swinhoe and Nacaduba beroe minima. Six endemic species are included in this undiscovered list. The other butterfly species are either highly localized (e.g. Graphium antiphates ceylonicus, Libythea celtis lepitoides, Lethe rohria neelgheriensis, Mycalesis rama, Prosotas noreia noreia) or very rare and have not been observed more than half a dozen within the past decade (e.g. Cepora nadina cingala (D. Podduwage pers. Comm.), Appias indra narendra, Junonia hierta hierta, Horaga onyx cingalensis, Horaga albimaculata viola, Tajuria arida, Rapala lankana (M. wickramasinghe pers. Comm.), Nacaduba ollyetti, Gangara lebadea subfasciata, Caprona alida lanka (S. de Silva pers. Comm.), Potanthus pallida (G. van der Pootern, pers. Comm.) and Potanthus pseudomaesa pseudomaesa). Spindasis nubilus and Rapala iarbus sorya have not been recorded in recent years.

A total of 480 plant species (more than $11 \%$ of total plant species present in Sri Lanka) representing 70 families are recorded as butterfly LFPs in the current study, 462 species are identified to the species level while the remaining 18 are identified only to the genus or family level. In Sri Lanka, 124 plant species (more than $25 \%$ of total LFPs) listed in this document are exotic, introduced as ornamentals, food crops, medicinal plants, symbolic plants, cover crops, or weeds with some introduced more than 2000 years ago. LFPs for 77 butterfly species include at least one exotic plant. Most of the Sri Lankan butterfly LFPs belong to the family Fabaceae, presently 104 species. The Poaceae take second place by having 31 species. Similarly, these two families are also reported in the top rank in the studies carried out at Andaman, Nicobar Islands and Nagpur city in India (Veenakumari et al., 1997; Tiple et al., 2010). Axonopus compressus (Poaceae) is used by nine butterfly species, the highest number of butterflies on a single foodplant.

Though the impact of exotic plant introductions on the distribution and population size of butterflies cannot be precisely determined without detailed historical data, the number of exotic LFPs and the number of butterflies that use exotic plants as LFPs implies that these plants have a significant impact on recent changes in Sri Lankan butterfly populations. The recent introduction of the exotic Plumbago capensis as an ornamental plant likely resulted 
in an increase in the population of Leptotes plinius plinius around Colombo, historically known from the dry zone (Woodhouse, 1949). Cycas revoluta is another introduced ornamental plant that is host to Chilades pandava lanka, even in the heart of the city of Colombo and is the only butterfly species in Sri Lanka that feeds on gymnosperms. Graphium sarpedon teredon and Lampides boeticus feed on the alien invasive species Annona glabra and Ulex europaeus, respectively. Everes lacturnus lacturnus has shifted to the recently introduced plant, Desmodium uncinatum (de Vlas \& de Vlas, 2008) and now the butterfly is common along railroads and abandoned lands

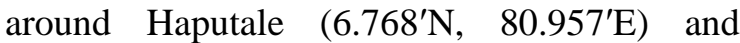
Bandarawela $\left(6.830^{\prime} \mathrm{N}, 80.988^{\prime} \mathrm{E}\right)$ where the plant is naturalized.

Since the initial identification of Catopsilia scylla in 2008, it appears the species has extended its range to the Mid Hills (Jayasinghe et al., 2013) and a breeding population has been observed on another exotic ornamental plant, Senna divaricata, at Laxapana $\left(6.9271^{\prime} \mathrm{N}\right.$, $80.4841^{\prime} \mathrm{E}$ ) in the western Mid Hills. Now it is also found commonly in eastern Mid Hills and it was observed laying eggs at Bandarawela on $S$. spectabilis, which is another exotic plant. The latter plant has become naturalized and spread up to Wellawaya and the butterfly also can be seen in between these locations. Recently it has been collected on a native plant - Senna tora - and sucessfully reared to adulthood. Hence its further spreading is expected into the dry zone, where $S$. tora is common. In a different example Cephrenes trichopepla has adapted to a native plant, Phoenix pusilla, in the dry zone after it was initially found in the western wet zone around Colombo. It is a worthwhile study to recognize the status of the Talicada nyseus nyseus, which was a common butterfly even in 1950's (Woodhouse, 1949). It's only known LFP in Sri Lanka is Kalanchoe pinnata, a native plant to Africa that is a now pantropical weed. There are only two other plant species of this family in Sri Lanka; $K$. laciniata and $K$. floribunda which are exceptionally rare in the wild (Dassanayake, 1999). Perhaps this butterfly also has come here with the introduced plant and then become naturalized or it was very rare before the introduction of $K$. pinnata and then became abundant as the exotic plant spread.
To date only four butterfly species were recorded to use a single LFP, each feeding on an exotic plant. Charaxes solon cerynthus feeds on Tamarindus indica, which was introduced to the Indian region at least 3000 years ago (de Vlas \& de Vlas, 2008). The much rarer Catapaecilma major myosotina is regularly found to feed on a Psidium guajava in a home garden at Etampitiya (6.9381N, 80.9870E). It has shown a symbiotic relationship with a Crematogaster ant, and there may be other plants that are used by this butterfly when the ants are present. Though Notocrypta curvifascia curvifascia is found only to feed on Zingiber zerumbet, it is most probable that it has other native plants hosts since many Zingibaraceae species are found in the butterfly's habitat. The endemic Ypthima singala has been successfully reared on Axonopus compressus in the lab after collecting eggs found on an unknown grass; at present no native LFP is known. This butterfly must have a native LFP and further studies should carry out to reveal it. The other endemic butterfly recorded feeding on exotic plants is Mycalesis subdita, however, only under lab conditions.

Many cases are known for when native plants that were restricted to a certain region were then planted into another region and then became host to a new breeding population of a butterfly. For example, Crataeva adansonii is naturally restricted to the low country dry zone (Dassanayake, 1996), especially in coastal areas but it is occasionally planted in the wet zone due to its medicinal and ornamental value. Appias lyncida taprobana uses this plant as its sole LFP and is also restricted to breed in dry lowlands, however, it also disperses all over the country in migratory flights. A continuous breeding population of $A$. lyncida was observed from 2003-2007 on C. adansonii planted in the wet zone at Katubedda. Apparently Appias adults populated a new point locality discovered as a result of their migrating behavior. Tylophora pauciflora is a rare plant in the dry zone (Dassanayake, 1983), which is now commonly planted in gardens in Colombo and vicinity, for its green leaves. Parantica aglea aglea readily use this plant as a LFP in these areas. There are 41 plant species which are endemic to Sri Lanka among the 342 native plants that are recorded as LFPs. Additional studies on butterfly LFPs are needed in protected areas where remnants of pristine 
habitats and the endemic flora could reveal new foodplant records.

Few butterfly caterpillars feed on economically important crops, but the impact on these crops by larvae are yet to be studied thoroughly. The main crop in Sri Lanka is rice, Oryza sativa, with production of 3,975,000 tons and covering 740,000 ha of land area $(11.8 \%$ of the total land area of the country) in year 2012 (Department of census and statistics, Sri Lanka, 2013). Rice is a crop that is used by eight species of butterflies, the highest number of butterfly species associated with a agricultural commodity. However, to date all of the records of these larvae feeding on rice were obtained from observations in a no-pesticide paddy field at Haldummulla. Only Parnara bada bada has been seen in high numbers while other species were found in very limited numbers. Vigna unguiculata and Phaseolus vulgaris are two other commercial crops which are suitable for Jamides bochus bochus and Jamides celeno tissama all over the country and for Euchrysops cnejus cnejus in the dry zone. In fact, these three species are pests and farmers rely on pesticides to overcome their larvae.

Some papilionids such as Papilio demoleus demoleus, Papilio polytes romulus and Papilio polymnestor parinda feed on various planted Citrus species, but do not cause severe damages. Though Virachola isocrates is a pest of many fruits in India (Woodhouse, 1949), it is restricted in Sri Lanka to the fruits of naturally growing Limonia acidissima. Eurema hecabe hecabe has some negative impact on Sesbania grandiflora saplings, but the impact ceases once the plant is grown up to a few feet high because female butterflies never fly above such a heights to lay eggs. Though the larvae of Jamides alecto meilichius consume seeds and flowers of Elettaria cardamomum it has not been observed that they are causing any significant damage. There are many other LFPs of this butterfly, in the vicinity of these plantations. Cheritra freja pseudojafra is recently found on Cinnamomum verum, but it is very unlikely to become a pest due to its scarcity. Papilio clytia lankeswara also feeds on $C$. verum, but its first preference is Litsea glutinosa, which is a common wild plant.

It is evident that most butterflies are restricted to certain species of plants save for few exceptions. Only 37 butterfly species are using LFPs of more than one plant family. Generalistfeeders are indeed the minority. Neptis hylas varmona is in the top rank for having greatest number of LFPs (30 species; six families), which is followed by Euploea core asela (29 species; two families), Jamides bochus bochus (20 species; one family) and Graphium agamemnon menides (20 species; two families). Having such a large number of LFPs contributes to the large populations and wide distribution of these butterflies. Among these 37 generalist-feeding species many use closely related plant families. Arhopala amantes amantes, Arhopala centaurus pirama, and Zesius chrysomallus feed on many plants irrespective of the family, but always where the ant, Oecophylla smaragdina, is colonized.

Sixty-seven species out of total 207 butterfly species listed here are recorded only with one LFP each. However, we suspect there must be more than one larval food plant for many of them and further studies should be carried out to discover additional relationships. Notably, only a few species seem to be limited to a single plant. Among the 67 single LFP species, nine are endemic to Sri Lanka and it is unlikely to have more than one LFP for many of these species. Also, LFPs of only eight species were identified up to now out of 21 critically endangered species (van der Pootern, 2012). Five of these species are reported only with a single LFP. The distribution of the critically endangered Phalanta alcippe ceylonica in Sri Lanka is highly localized, where it is known from wet zone slopes of Knuckles Mountain Range (approx. $7.381^{\prime} \mathrm{N}, 80.851^{\prime} \mathrm{E}$ ). Its sole LFP, Rinorea decora, is endemic to this mountain range (Dassanayake, 1996) and is exceptionally rare, treated as an "Extinct" species in the Red Data List, 2012. Recently, Phalanta alcippe was recorded in a forest patch within the premises of University of Sabaragamuwa $\quad\left(6.710^{\prime} \mathrm{N}, \quad 80.791^{\prime} \mathrm{E}\right) \quad(\mathrm{S}$. Morawaka pers. Comm. 2013), where it was previously mentioned only as "It has been taken very rarely in Rathnapura District" by Woodhouse (1949), with no exact location and with some uncertainty. Two other probable LFPs that can occur in the Rathnapura District are $R$. virgata and $R$. bengalensis which are treated as "Vulnerable" and "Extinct" respectively in Red Data List, 2012. Immediate remedial actions have to be taken to propagate 
the plants of this genus to ensure the conservation of this unique butterfly.

Recently, the critically endangered Catochrysops panormus panormus was found feeding on Flemingia macrophylla, previously treated as "possibly extinct" in Red Data list, 2012. This plant is quite common in that location, but we have only seen a single plant cluster beyond this location. Another six critically endangered butterfly species are using fairly common plants as their LFPs. Detailed studies on micro requirements are of prime importance to conserve both these endemic and critically endangered species.

The listing of LFPs for butterflies remains a work-in-progress. New reords are yet to be discovered, including, the recording of LFPs for the remaining butterflies with no known food plants and additional LFPs for butterflies with already known LFPs and to determine micro requirements of those butterflies such as food preference, micro habitat requirements, symbiotic relationship with ants, parasitism, and the population dynamics of butterflies in relation to life cycle dynamics of their LFPs. There is a possibility of adding numerous Poaceae species to the list, since we did not pay much attention to this family due to difficulties in identification of species. Finally, it is recommended that government agencies and other interested parties use these research data in their conservation management of the butterfly fauna in Sri Lanka.

\section{Acknowledgements}

We thank van der Pootern for valuable advice, information both in the field and preparation the manuscript; van der Pootern, S. Karunaarachchi, A. Keshan, S. Gunasena, L. Aberathne, R. Samanmalee, T. Ranasinghe, S. Wellappuliarachchi, D. Danushka, H. Kularathne, I. Wijewardhane, M. Wickramasinghe, S. Morawaka, D. Podduwage, and S. de Silva for personal communications; J. de Vlas for generous help in identification of some plants; and S. Thrikawala for the help in writing the manuscript. We also thank the Department of Wildlife Conservation and the Department of Forest Conservation, Sri Lanka for giving permission to conduct this research.

\section{Literature cited}

APG III [Bremer, B., K. Bremer, M. W. Chase, M. F. Fay, J. L. Reveal, D. E. Soltis, P. S. Soltis, and P. F. Stevens (comp.)]. 2009. An update of the Angiosperm Phylogeny Group classification for the orders and families of flowering plants: APG III. Botanical Journal of the Linnean Society, 161: 105-121.

Bernays, E. and R. Chapman, 1994. Host-Plant Selection by Phytophagous Insects. Chapman and Hall Publication, London.

Boppré, M., 1984. Chemically mediated interactions between butterflies. Pp. 259-275. In: Vane-Wright, R. I., and P. R. Ackery (eds.). The Biology of Butterflies. Royal Entomological Society, London.

d'Abrera, B., 1998. The Butterflies of Ceylon. Wildlife Heritage Trust, Colombo, Sri Lanka.

Dassanayake, M. D. (ed.), 1980. A Revised Handbook to the Flora of Ceylon, Vol. 1. Amerind Publishing Co. Pvt. Ltd., New Delhi, India.

Dassanayake, M. D. (ed.), 1981a. A Revised Handbook to the Flora of Ceylon, Vol. 2. Oxford and IBH Publishing Co., New Delhi, India.

Dassanayake, M. D. (ed.), 1981b. A Revised Handbook to the Flora of Ceylon, Vol. 3. Oxford and IBH Publishing Co., New Delhi, India.

Dassanayake, M. D. (ed.), 1983. A Revised Handbook to the Flora of Ceylon, Vol. 4. Amerind Publishing Co. Pvt. Ltd., New Delhi, India.

Dassanayake, M. D. (ed.), 1985. A Revised Handbook to the Flora of Ceylon, Vol. 5. Oxford and IBH Publishing Co., New Delhi, India.

Dassanayake, M. D. (ed.), 1987. A Revised Handbook to the Flora of Ceylon, Vol. 6. Oxford and IBH Publishing Co., New Delhi, India.

Dassanayake, M. D. (ed.), 1991. A Revised Handbook to the Flora of Ceylon, Vol. 7. Amerind Publishing Co. Pvt. Ltd., New Delhi, India.

Dassanayake, M. D. (ed.), 1994. A Revised Handbook to the Flora of Ceylon, Vol. 8. Oxford and IBH Publishing Co., New Delhi, India. 
Dassanayake, M. D. (ed.), 1995. A Revised Handbook to the Flora of Ceylon, Vol. 9. Amerind Publishing Co. Pvt. Ltd., New Delhi, India.

Dassanayake, M. D. (ed.), 1996. A Revised handbook to the flora of Ceylon, Vol. 10, Oxford and IBH Publishing Co., New Delhi, India.

Dassanayake, M. D. (ed.), 1997. A Revised Handbook to the Flora of Ceylon, Vol. 11. Oxford and IBH Publishing Co., New Delhi, India.

Dassanayake, M. D. (ed.), 1998. A Revised Handbook to the Flora of Ceylon, Vol. 12. Oxford \& IBH Publishing Co., New Delhi, India.

Dassanayake, M. D. (ed.) 1999. A Revised Handbook to the Flora of Ceylon, Vol. 13. Oxford \& IBH Publishing Co., New Delhi, India.

Dassanayake, M. D. (ed.), 2000. A Revised Handbook to the Flora of Ceylon, Vol. 14. Oxford and IBH Publishing Co., New Delhi, India.

Department of Census and Statistics, Sri Lanka, 2013. <http://www.statistics.gov.lk/agriculture/ Paddy\%20Statistics/PaddyStats.htm>, accessed 12 October 2013.

Dias, R. K. S., 2002. Ants of Sri Lanka. Vishva Lekah Publishers, Ratmalana, Sri Lanka.

Ehrlich, P. R. and D. D. Murphy, 1988. Plant chemistry and host range in insect herbivores. Ecology, 69: 908-909.

Fernando, S. S. and P. Ormerod, 2008. An annotated checklist of the orchids of Sri Lanka, Rheedia, 18: 1-28.

Jayasinghe, H. D., C. de Alwis, and S. S. Rajapakshe, 2013. Sri Lankan butterflies, a website. <http://www.slbutterflies.com>, accessed 12 October 2013.

Jayasinghe, H. D., C. de Alwis, and S. S. Rajapaksha, 2013. A Pocket Guide to the Butterflies of Sri Lanka. Butterfly Conservation Society of Sri Lanka, Colombo.

Kawahara A. Y., 2013. Systematic revision and review of the extant and fossil snout butterflies (Lepidoptera: Nymphalidae: Libytheinae). Zootaxa, 3631: 01-74.
Kunte, K., 2000. Butterflies of Peninsular India. Universities Press (India) Ltd., Hyderabad. India. Moore, F., 1880. The Lepidoptera of Ceylon. Vol. I. L. Reeve and Co., London.

Moore, F., 1884-1887. The Lepidoptera of Ceylon. Vol. III. L. Reeve and Co., London.

Ormiston, W., 1924. The Butterflies of Ceylon. H. W. Cave and Co., Colombo.

Robinson, G. S., P. R. Ackery, I. J. Kitching, G. W. Beccaloni, and L. M. Hernández, 2010. HOSTS - A database of the world's Lepidopteran hostplants. Natural History Museum, London. <http://www.nhm.ac.uk/hosts〉, accessed 29 September 2013.

Senarathna, L. K., 2001. A Check List of the Flowering Plants of Sri Lanka. National Science Foundation, Colombo, Sri Lanka.

Tiple, A. D., A. M. Khurad, and R. L. H. Dennis, 2010. Butterfly larval host plant use in a tropical urban context: Life history associations, herbivory, and landscape factors. Journal of Insect Science, 11: 1-21.

van der Poorten, G., 2012. The taxonomy and conservation status of the butterflies of Sri Lanka. Pp. 26-41. In: D. K. Weerakoon and S. Wijesundara (eds.), The National Red List 2012 of Sri Lanka; Conservation Status of the Fauna and Flora. Ministry of Environment, Colombo.

van der Poorten, G. and N. van der Poorten, 2011a. New and revised descriptions of the immature stages of some butterflies in Sri Lanka and their larval food plants (Lepidoptera: Nymphalidae). Part 1: Sub-family Danainae. The Journal of Research on the Lepidoptera, 44: 116.

van der Poorten, G. and N. van der Poorten, 2011b. New and revised descriptions of the immature stages of some butterflies in Sri Lanka and their larval food plants (Lepidoptera: Papilionidae). The Journal of Research on the Lepidoptera, 44: 111-127.

van der Poorten, G. and N. van der Poorten, 2012a. Catopsilia scylla (Linnaeus, 1763): A new record for Sri Lanka with notes on its biology, life history and distribution (Lepidoptera: Pieridae). The Journal of Research on the Lepidoptera, 45: 17-23. 
van der Poorten, G. and N. van der Poorten, 2012b. New and revised descriptions of the immature stages of some butterflies in Sri Lanka and their larval food plants (Lepidoptera: Nymphalidae). Part 2: Subfamily Satyrinae. Tropical Lepidoptera, 22: 80-92.

van der Poorten, G. and N. van der Poorten, 2012c. The biology of Spindasis greeni Heron, 1896 and a review of the genus Spindasis in Sri Lanka (Lepidoptera: Lycaenidae). The Journal of Research on the Lepidoptera, 45: 119-133.

van der Poorten, G. and N. van der Poorten, 2012d. Cephrenes trichopepla (Lower, 1908): A new record for Sri Lanka with notes on its biology, life history and distribution (Lepidoptera: Hesperiidae). Tijdschrift voor Entomologie, 156: 95-101.

van der Poorten, G. and N. van der Poorten, 2013a. New and revised descriptions of the immature stages of some butterflies in Sri Lanka and their larval food plants (Lepidoptera: Lycaenidae). Part 1: Polyommatinae and Theclinae, in part. The Journal of Research on the Lepidoptera, 46: 25-49.

van der Poorten, G. and N. van der Poorten, 2013b. New and revised descriptions of the immature stages of some butterflies in Sri Lanka and their larval food plants (Lepidoptera : Pieridae). Part 1 : Subfamilies Pierini (in part) and Coliadinae. Tropical Lepidoptera, 23: 22-31.

van Nieukerken, E. K., L. Kaila, I. J. Kitching, N. P. Kristensen, D. C. Lees, J. Minet, C. Mitter, M. Mutanen, J. C. Regier, T. J. Simonsen, N. Wahlberg, S. H. Yen, R. Zahiri, D. Adamski, J. Baixeras, D. Bartsch, B. A. Bengtsson, J. W. S. R. Brown, D. R. Bucheli, J. Davis, W. De Prins, M. E. De Prins, P. Epstein, C. Gentili-Poole, P. Gielis, A. Hättenschwiler, J. D. Hausmann, A. Holloway, O. Kallies, A. Y. Karsholt, S. J. C. Kawahara, M . Koster, V. Kozlov, J. D. Lafontaine, G. Lamas, J. F. Landry, S. Lee, M. Nuss, K. T. Park, C. Penz, J. Rota, A. Schintlmeister, B. C. Schmidt, J. C. Sohn, M. A. Solis, G. M. Tarmann, A. D. Warren, S. Weller, R. V. Yakovlev, V. V. Zolotuhin, and A. Zwick, 2011. Order Lepidoptera Linnaeus, 1758. In: Zhang, Z.-Q. (ed.) Animal biodiversity: An outline of higher-level classification and survey of taxonomic richness. Zootaxa, 3148: 212-221.
Vane-Wright, R. I., 1978. Ecological and behavioural origins of diversity in butterflies. Pp. 56-70. In: Mound, L. A., and N. Waloff (eds.). Diversity of Insect faunas. Oxford University press, Blackwell Publishers: 56-70.

Veenakumari, K., P. Mohanraj, and P. V. Sreekumar, 1997. Host plant utilization by butterfly larvae in the Andaman and Nicobar Islands (Indian Ocean). Journal of Insect Conservation, 1: 235- 46.

Vlas, J. and J. Vlas, 2008. Illustrated Field Guide to the Flowers of Sri Lanka, Volume I. Mark Booksellers and Distributors (Pvt) Ltd, Kandy.

Ward, L. K. and D. F. Spalding, 1993. Phytophagous British insects and mites and their food-plant families: Total numbers and polyphagy. Biological Journal of the Linnean Society, 49: 257-276.

Woodhouse, L. G. O., 1949. The butterfly fauna of Ceylon. Second Complete Edition. The Colombo Apothecaries' Co. Ltd., Colombo.

Wiklund, C., 1975. The evolutionary relationship between adult oviposition preferences and larval host plant range in Papilio machaon L. Oecolgia, 18: 185-197.

Wiklund, C., 1984. Egg-laying patterns in butterflies in relation to their phenology and the visual apparency and abundance of their host plants. Oecologia, 63: 23-29. 
Appendix 1: Larval food plants of butterflies of Sri Lanka (*see editor's end note below); **, reported for the first time in Sri Lanka as a feeding plant; *, conforemations of previous studies during this study; L, leaves; S, green stem; F, flowers / flower pods; R, exposed or ariel roots; I, Inflorescence; Im, immature; Mt, mature; ${ }^{\text {En }}$, endemic; ${ }^{\text {In}}$ : Indigenous, ${ }^{\text {Ex}}$ : Exotic; PC, Personal Communication.

\begin{tabular}{|c|c|c|c|c|}
\hline Butterfly species & Feeding plant species & Plant family & $\begin{array}{c}\text { Feeding } \\
\text { part }\end{array}$ & Note \\
\hline \multicolumn{5}{|c|}{$\begin{array}{ll}\text { Papilionidae } \\
\end{array}$} \\
\hline Troides darsius & Aristolochia indica $*^{\text {In }}$ & Aristolochiaceae & $\mathrm{L}, \mathrm{S}$ & \\
\hline \multirow{3}{*}{ Pachliopta hector } & Aristolochia bracteolata $*$ In & \multirow{3}{*}{ Aristolochiaceae } & \multirow{3}{*}{$\mathrm{L}, \mathrm{S}, \mathrm{F}$} & \\
\hline & Aristolochia indica $*{ }^{I n}$ & & & \\
\hline & Aristolochia ringens $* E x$ & & & \\
\hline Pachliopta jophon & Thottea siliquosa $*$ In & Aristolochiaceae & $\mathrm{L}$ & \\
\hline \multirow{4}{*}{$\begin{array}{l}\text { Pachliopta aristolochiae } \\
\text { ceylonica }\end{array}$} & Aristolochia bracteolata $*$ In & \multirow{4}{*}{ Aristolochiaceae } & \multirow{3}{*}{$\mathrm{L}, \mathrm{S}$} & \\
\hline & Aristolochia indica $*$ In & & & \\
\hline & Aristolochia ringens $* E x$ & & & \\
\hline & Thottea siliquosa $*$ In & & $\mathrm{L}$ & \\
\hline \multirow{3}{*}{ Papilio crino } & Chloroxylon swietenia $*{ }^{I n}$ & \multirow{3}{*}{ Rutaceae } & \multirow{3}{*}{$\mathrm{L}$} & \\
\hline & Clausena indica ${ }^{\ln }$ & & & \\
\hline & Toddalia asiatica ${ }^{I n}$ & & & \\
\hline \multirow{11}{*}{ Papilio demoleus demoleus } & Cullen corylifolium ${ }^{* I n}$ & Fabaceae & \multirow{11}{*}{$\mathrm{L}$} & \\
\hline & Aegle marmelos ${ }^{*}$ Ex & \multirow{10}{*}{ Rutaceae } & & \\
\hline & Atalantia ceylanica ${ }^{* *} I n$ & & & \\
\hline & Chloroxylon swietenia ${ }^{*}$ In & & & \\
\hline & Citrus aurantiifolia ${ }^{*} E x$ & & & \\
\hline & Citrus limon $^{* E x}$ & & & \\
\hline & Citrus sinensis ${ }^{* *} E x$ & & & \\
\hline & Euodia suaveolens ${ }^{* *}$ Ex & & & PC: S. Umesh \\
\hline & Glycosmis pentaphylla *In & & & \\
\hline & Limonia acidissima $^{* I n}$ & & & \\
\hline & Pamburus missionis ${ }^{* *} I n$ & & & \\
\hline \multirow{3}{*}{ Papilio helenus mooreanus } & Citrus japonica $^{* * E x}$ & \multirow{3}{*}{ Rutaceae } & \multirow{3}{*}{$\mathrm{L}$} & \\
\hline & Toddalia asiatica ${ }^{* I n}$ & & & \\
\hline & Zanthoxylum tetraspermum ${ }^{* * I n}$ & & & \\
\hline \multirow{14}{*}{ Papilio polytes romulus } & Atalantia ceylanica ${ }^{* I n}$ & \multirow{14}{*}{ Rutaceae } & \multirow{14}{*}{$\mathrm{L}$} & \\
\hline & Citrus aurantiifolia ${ }^{*} E x$ & & & \\
\hline & Citrus limon ${ }^{*} E x$ & & & \\
\hline & Citrus maxima ${ }^{* * E x}$ & & & \\
\hline & Citrus sinensis ${ }^{*}$ Ex & & & \\
\hline & Glycosmis angustifolia $^{* * I n}$ & & & \\
\hline & Glycosmis mauritiana $^{* *} \operatorname{In}$ & & & \\
\hline & Glycosmis pentaphylla ${ }^{* I n}$ & & & \\
\hline & Limonia acidissima $^{* * I n}$ & & & \\
\hline & Micromelum minutum ${ }^{*}$ En & & & \\
\hline & Murraya koenigii ${ }^{*} \operatorname{In}$ & & & \\
\hline & Murraya paniculata ${ }^{* * I n}$ & & & \\
\hline & Pleiospermium alatum ${ }^{* I n}$ & & & \\
\hline & Toddalia asiatica ${ }^{* I n}$ & & & \\
\hline \multirow{8}{*}{ Papilio polymnestor parinda } & Atalantia ceylanica $^{*}$ In & & & \\
\hline & Atalantia monophylla ${ }^{I n}$ & & & \\
\hline & Atalantia rotundifolia ${ }^{* *} I n$ & & & \\
\hline & Citrus aurantiifolia ${ }^{*} E x$ & Putocono & & \\
\hline & Citrus maxima $^{E x}$ & Rutaceae & $\mathrm{L}$ & \\
\hline & Citrus reticulata $^{E x}$ & & & \\
\hline & Citrus sinensis ${ }^{*}$ Ex & & & \\
\hline & Paramignya monophylla ${ }^{* I n}$ & & & \\
\hline & Alseodaphne semecarpifolia ${ }^{* *} \operatorname{In}$ & & & \\
\hline Papilio clytia lankeswara & Cinnamomum verum ${ }^{* I n}$ & Lauraceae & $\mathrm{L}$ & \\
\hline & Litsea glutinosa $^{* I n}$ & & & \\
\hline
\end{tabular}




\begin{tabular}{|c|c|c|c|c|}
\hline & Litsea longifolia ${ }^{* *} E n$ & & & \\
\hline & Neolitsea cassia ${ }^{* *} \operatorname{In}$ & & & \\
\hline \multirow{8}{*}{ Graphium sarpedon teredon } & Actinodaphne stenophylla ${ }^{* * E n}$ & \multirow{8}{*}{ Lauraceae } & \multirow{8}{*}{$\mathrm{L}$} & \\
\hline & Cinnamomum cappara-coronde $^{\text {En }}$ & & & \\
\hline & Cinnamoтum dubium ${ }^{\text {En }}$ & & & \\
\hline & Cinnamomum ovalifolium $^{* * E n}$ & & & \\
\hline & Cinnamomum verum ${ }^{* I n}$ & & & \\
\hline & Litsea gardneri ${ }^{* *} E n$ & & & \\
\hline & Neolitsea cassia ${ }^{* I n}$ & & & \\
\hline & Neolitsea fuscata ${ }^{*}$ En & & & \\
\hline \multirow{3}{*}{ Graphium doson doson } & Miliusa indica ${ }^{\text {In }}$ & \multirow{3}{*}{ Annonaceae } & \multirow{3}{*}{$\mathrm{L}$} & Only in the lab \\
\hline & Polyalthia korinti ${ }^{* I n}$ & & & \\
\hline & Uvaria macropoda ${ }^{* / n}$ & & & \\
\hline \multirow{20}{*}{ Graphium agamemnon menides } & Annona cherimola ${ }^{*}$ Ex & \multirow{19}{*}{ Annonaceae } & \multirow{20}{*}{$\mathrm{L}$} & \\
\hline & Annona glabra ${ }^{* E x}$ & & & \\
\hline & Annona muricata ${ }^{* E x}$ & & & \\
\hline & Annona reticulata ${ }^{* E x}$ & & & \\
\hline & Annona squamosa ${ }^{*}$ Ex & & & \\
\hline & Artabotrys hexapetalus ${ }^{* I n}$ & & & \\
\hline & Artabotrys zeylanicus ${ }^{* * I n}$ & & & \\
\hline & Miliusa indica ${ }^{* I n}$ & & & \\
\hline & Miliusa tomentosa ${ }^{* / n}$ & & & \\
\hline & Persea americana ${ }^{* E x}$ & & & \\
\hline & Polyalthia cerasoides ${ }^{*}$ In & & & \\
\hline & Polyalthia korinti ${ }^{* * I n}$ & & & \\
\hline & Polyalthia longifolia ${ }^{* * I n}$ & & & \\
\hline & Polyalthia suberosa ${ }^{* I n}$ & & & \\
\hline & Uvaria macropoda $^{* I n}$ & & & \\
\hline & Uvaria narum $^{* * I n}$ & & & \\
\hline & Uvaria semecarpifolia $^{* * E n}$ & & & \\
\hline & Uvaria sphenocarpa ${ }^{* E n}$ & & & \\
\hline & Xylopia championii ${ }^{* *}$ En & & & \\
\hline & Magnolia champaca ${ }^{* I n}$ & Magnoliaceae & & \\
\hline Graphium nomius nomius & Miliusa tomentosa ${ }^{* I n}$ & Annonaceae & $\mathrm{L}$ & \\
\hline \multicolumn{5}{|c|}{$\begin{array}{ll}\text { Pieridae } \\
\end{array}$} \\
\hline \multirow{6}{*}{ Leptosia nina nina } & Cardamine hirsuta ${ }^{* * I n}$ & \multirow{2}{*}{ Brassicaceae } & \multirow{6}{*}{$\mathrm{L}$} & \\
\hline & Nasturtium officinale ${ }^{* * E x}$ & & & \\
\hline & Capparis zeylanica ${ }^{* *} \operatorname{In}$ & Capparaceae & & \\
\hline & Cleome gynandra ${ }^{* * I n}$ & \multirow{3}{*}{ Cleomaceae } & & \\
\hline & Cleome rutidosperma ${ }^{* *} E x$ & & & \\
\hline & Cleome viscosa ${ }^{* *} I n$ & & & \\
\hline \multirow{6}{*}{ Delias eucharis } & Dendrophthoe falcata ${ }^{* * I n}$ & \multirow{6}{*}{ Loranthaceae } & \multirow{6}{*}{$\mathrm{L}$} & \\
\hline & Dendrophthoe ligulatus ${ }^{* * E n}$ & & & \\
\hline & Dendrophthoe neelgherrensis ${ }^{* * I n}$ & & & \\
\hline & Scurrula cordifolia $^{* * E n}$ & & & \\
\hline & Scurrula parasitica ${ }^{* * I n}$ & & & \\
\hline & Taxillus tomentosus ${ }^{* * I n}$ & & & \\
\hline Prioneris sita & Capparis moonii $^{* * I n}$ & Capparaceae & $\mathrm{L}$ & \\
\hline \multirow{5}{*}{ Belenois aurota taprobana } & Cadaba trifoliata ${ }^{* *} I n$ & & & PC: v. Pootern \\
\hline & Capparis grandis ${ }^{* * I n}$ & & & \\
\hline & Capparis sepiaria $^{* * 1 n}$ & Capparaceae & $\mathrm{L}$ & \\
\hline & Capparis zeylanica $^{* * I n}$ & & & \\
\hline & Maerua arenaria ${ }^{* * / n}$ & & & \\
\hline & Capparis brevispina ${ }^{* * I n}$ & & & \\
\hline & Capparis grandis ${ }^{* * 1 n}$ & & & \\
\hline Cepora nerissa phryne & Capparis moonii $^{* * I n}$ & Capparaceae & $\mathrm{L}$ & \\
\hline & Capparis roxburghii ${ }^{* * I n}$ & & & \\
\hline & Capparis sepiaria $^{* * I n}$ & & & \\
\hline
\end{tabular}




\begin{tabular}{|c|c|c|c|c|}
\hline & Capparis zeylanica ${ }^{* *} I n$ & & & \\
\hline & Crateva adansonii $^{* * I n}$ & & & \\
\hline \multirow{4}{*}{ Appias libythea libythea } & Cadaba fruticosa ${ }^{I n}$ & \multirow{4}{*}{ Capparaceae } & \multirow{4}{*}{$\mathrm{L}$} & \\
\hline & Capparis grandis ${ }^{* I n}$ & & & \\
\hline & Capparis roxburghii ${ }^{I n}$ & & & \\
\hline & Crateva adansonii $^{* I n}$ & & & \\
\hline Appias lyncida taprobana & Crateva adansonii $^{* \operatorname{In}}$ & Capparaceae & $\mathrm{L}$ & \\
\hline \multirow{2}{*}{ Appias galene } & Drypetes gardneri ${ }^{* * E n}$ & \multirow{2}{*}{ Putranjivaceae } & \multirow{2}{*}{$\operatorname{Im~L}$} & found only ovipositing \\
\hline & Drypetes sepiaria $^{* I n}$ & & & \\
\hline \multirow{3}{*}{ Ixias marianne } & Capparis brevispina ${ }^{* * / n}$ & \multirow{3}{*}{ Capparaceae } & \multirow{3}{*}{$\mathrm{L}$} & \\
\hline & Capparis grandis ${ }^{* *} I n$ & & & \\
\hline & Capparis sepiaria $^{* *} \operatorname{In}$ & & & \\
\hline \multirow{2}{*}{ Ixias pyrene cingalensis } & Capparis grandis ${ }^{* *} / n$ & \multirow{2}{*}{ Capparaceae } & \multirow{2}{*}{$\mathrm{L}$} & \\
\hline & Capparis sepiaria $^{* *} \operatorname{In}$ & & & \\
\hline Hebomoia glaucippe ceylonica & Capparis moonii $^{* * \operatorname{In}}$ & Capparaceae & $\mathrm{L}$ & \\
\hline \multirow{9}{*}{ Catopsilia pyranthe pyranthe } & Cassia fistula $^{* E x}$ & \multirow{9}{*}{ Fabaceae } & \multirow{9}{*}{$\mathrm{L}$} & \\
\hline & Cassia roxburghii $^{* * *}$ & & & \\
\hline & Senna alata ${ }^{*} E x$ & & & \\
\hline & Senna auriculata ${ }^{* / n}$ & & & \\
\hline & Senna didymobotrya ${ }^{* *} E x$ & & & \\
\hline & Senna hirsuta ${ }^{* *} \operatorname{In}$ & & & \\
\hline & Senna occidentalis ${ }^{*}$ In & & & \\
\hline & Senna surattensis ${ }^{E x}$ & & & \\
\hline & Senna tora ${ }^{*}$ In & & & \\
\hline \multirow{7}{*}{ Catopsilia pomona pomona } & Cassia fistula ${ }^{*}$ Ex & \multirow{7}{*}{ Fabaceae } & \multirow{7}{*}{$\mathrm{L}$} & \\
\hline & Cassia grandis ${ }^{*}$ Ex & & & \\
\hline & Cassia javanica $^{*} E x$ & & & \\
\hline & Cassia roxburghii $^{* I n}$ & & & \\
\hline & Senna alata ${ }^{*}$ Ex & & & \\
\hline & Senna didymobotrya ${ }^{* E x}$ & & & \\
\hline & Senna surattensis ${ }^{E x}$ & & & \\
\hline & Cassia auriculata $^{\text {In }}$ & & & found only ovipositing \\
\hline & Senna divaricata ${ }^{* *} E x$ & & & \\
\hline Catopsilia scylla & Senna spectabilis ${ }^{* *}$ Ex & Fabaceae & $\mathrm{L}$ & found only ovipositing \\
\hline & Senna surattensis ${ }^{*}$ Ex & & & \\
\hline & Senna tora ${ }^{* * I n}$ & & & PC: N. Chaturanga \\
\hline Pareronia ceylanica ceylanica & Capparis zeylanica ${ }^{* *} \mid n$ & Capparaceae & Mt L & \\
\hline Colotis amata modesta & Azima tetracantha ${ }^{* *} \operatorname{In}$ & Salvadoraceae & $\mathrm{I}$ & \\
\hline Colotis amata moaesta & Salvadora persica ${ }^{* * I n}$ & salvadoraceae & L & \\
\hline Colotis fausta fulvia & Maerua arenaria ${ }^{* *} I n$ & Capparaceae & $\mathrm{L}$ & \\
\hline Colotis danae danae & Cadaba fruticosa ${ }^{* *} I n$ & Capparaceae & $\mathrm{L}$ & \\
\hline Colotis aurora & Cadaba fruticosa ${ }^{* * I n}$ & Capparaceae & $\mathrm{L}$ & \\
\hline Colotis etrida & Maerua arenaria ${ }^{* *} \operatorname{In}$ & Capparaceae & $\mathrm{L}$ & \\
\hline & Chamaecrista auricoma ${ }^{* *} \operatorname{In}$ & & & \\
\hline & Chamaecrista kleinii $^{* I n}$ & & & \\
\hline Eurema brigitta rubella & Chamaecrista mimosoides ${ }^{*} I n$ & Fabaceae & $\mathrm{L}$ & \\
\hline & Chamaecrista nictitans $^{* *}{ }^{\prime \prime n}$ & & & \\
\hline & Chamaecrista sp. $^{* *}$ & & & \\
\hline & Chamaecrista auricoma ${ }^{* * I n}$ & & & \\
\hline Furema laeta rama & ${\text { Chamaecrista } \text { kleinii }^{*} \text { In }}$ & Fahaceae & $\mathrm{I}$ & \\
\hline ситета саеьа rama & Chamaecrista mimosoides ${ }^{*}$ In & radacede & L & \\
\hline & Chamaecrista nictitans ${ }^{* *} \operatorname{In}$ & & & \\
\hline & Acacia eburnea ${ }^{* I n}$ & & & \\
\hline & Acacia leucophloea $^{\text {In }}$ & & & \\
\hline Furema hecahe hecabe & Aeschynomene americana ${ }^{*} E x$ & Fabaceae & $\mathrm{I}$ & \\
\hline surema nесаве песаве & Aeschynomene aspera ${ }^{* I n}$ & raoacede & L & \\
\hline & Aeschynomene indica ${ }^{* * I n}$ & & & \\
\hline & Albizia chinensis ${ }^{* *}$ Ex & & & \\
\hline
\end{tabular}




\begin{tabular}{|c|c|c|c|c|}
\hline & Albizia lebbeck $^{* * I n}$ & & & \\
\hline & Albizia odoratissima ${ }^{I n}$ & & & \\
\hline & Caesalpinia hymenocarpa ${ }^{* *}{ }^{\prime n}$ & & & \\
\hline & Caesalpinia pulcherrima ${ }^{* *}$ Ex & & & \\
\hline & Cassia roxburghii ${ }^{* *}$ In & & & \\
\hline & Pithecellobium dulce ${ }^{* E x}$ & & & \\
\hline & Senna alata ${ }^{* *} \mathrm{Ex}$ & & & \\
\hline & Senna tora ${ }^{* I n}$ & & & PC: A. Keshan \\
\hline & Sesbania bispinosa ${ }^{* * I n}$ & & & \\
\hline & Sesbania grandiflora ${ }^{*} E x$ & & & \\
\hline & Sesbania speciosa ${ }^{* * E x}$ & & & \\
\hline & Sesbania sp. ${ }^{* *}$ & & & \\
\hline & Vachellia nilotica $^{E x}$ & & & \\
\hline & Albizia chinensis ${ }^{* *} E x$ & & & \\
\hline & Albizia lebbeck ${ }^{* * I n}$ & & & \\
\hline & Albizia odoratissima ${ }^{I n}$ & & & \\
\hline & Archidendron bigeminum ${ }^{*}$ En & & & \\
\hline & Caesalpinia bonduc ${ }^{* * I n}$ & & & \\
\hline & Caesalpinia hymenocarpa ${ }^{* * 1 n}$ & & & \\
\hline Eurema blanda citrina & Cassia fistula ${ }^{* E x}$ & Fabaceae & $\mathrm{L}$ & \\
\hline | & Entada rheede ${ }^{*}{ }^{*}$ In & & & \\
\hline & Falcataria moluccana ${ }^{* E x}$ & & & \\
\hline & Senna alata ${ }^{* *} E x$ & & & PC: S. Gunasena \\
\hline & Senna surattensis ${ }^{*}$ Ex & & & \\
\hline & Calliandra surinamensis ${ }^{*}{ }^{E x}$ & & & \\
\hline & Ventilago gamblei $^{* I n}$ & & & \\
\hline Eurema ormistoni & Ventilago maderaspatana ${ }^{*}{ }^{I n}$ & Rhamnaceae & $\operatorname{Im~L}$ & \\
\hline & Nymphalida & & & \\
\hline Idea iasonia & Parsonsia alboflavescens ${ }^{* I n}$ & Apocynaceae & $\mathrm{L}$ & \\
\hline Idenncis cimilis oxnromnta & Parsonsia alboflavescens ${ }^{I n}$ & Anocynaceae & & found only ovipositing \\
\hline Ideopsls simills exprompta & Tylophora indica ${ }^{* I n}$ & Apocynaceae & $\mathrm{L}$ & \\
\hline Tirumala limniace exoticus & Dregea volubilis ${ }^{* I n}$ & Apocynaceae & $\mathrm{L}$ & \\
\hline & Dregea volubilis ${ }^{*}$ In & & & \\
\hline Tirumala septentrionis & Heterostemma tanjorensis ${ }^{*}$ In & Apocynaceae & $\mathrm{L}$ & only in the lab \\
\hline & Unidentified sp. & & & \\
\hline & Ceropegia candelabrum ${ }^{* * I n}$ & & & \\
\hline & Heterostemma tanjorensis ${ }^{*}$ In & & & \\
\hline & Tylophora indica ${ }^{*}{ }^{* \ln }$ & & & \\
\hline Parantica aglea aglea & Tylophora flexuosa ${ }^{* I n}$ & Apocynaceae & $\mathrm{L}$ & \\
\hline & Tylophora multiflora ${ }^{* * I n}$ & & & \\
\hline & Tylophora pauciflora ${ }^{* * I n}$ & & & \\
\hline & Ceropegia elegans ${ }^{* * I n}$ & & $\mathrm{~L}, \mathrm{~F}$ & \\
\hline & Cynanchum alatum $^{\text {In }}$ & & & \\
\hline Danartio tammata & Tylophora cordifolia ${ }^{\text {ln }}$ & 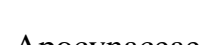 & & found only ovipositing \\
\hline Parantica taprobana & Tylophora multiflora ${ }^{* * I n}$ & Apocynaceae & $\mathrm{L}$ & \\
\hline & Tylophora pauciflora ${ }^{I n}$ & & & only in the lab \\
\hline & Tylophora sp. & & & \\
\hline & Asclepias curassavica ${ }^{*}$ Ex & & $\mathrm{L}$ & \\
\hline & Calotropis gigantea ${ }^{* I n}$ & & $\mathrm{~L}, \mathrm{~F}$ & \\
\hline Danau shruxinnu shrusinnu & Cynanchum tunicatum ${ }^{* *}$ In & A nосуиясеое & & \\
\hline Danaus chrysippus chrysippus & Gomphocarpus physocarpus ${ }^{*}$ Ex & Apocynaceae & $\mathrm{I}$ & \\
\hline & Pentatropis capensis ${ }^{* I n}$ & & $\mathrm{~L}$ & \\
\hline & Pergularia daemia ${ }^{* * I n}$ & & & \\
\hline & Cynanchum tunicatum ${ }^{* I n}$ & & & \\
\hline & Holostemma ada-kodien ${ }^{* * 1 n}$ & & & \\
\hline Danaus genutia genutia & Oxystelma esculentum ${ }^{* I n}$ & Apocynaceae & $\mathrm{L}$ & \\
\hline & Pentatropis capensis ${ }^{* * I n}$ & & & \\
\hline & Tylophora tenuissima ${ }^{\text {In }}$ & & & \\
\hline
\end{tabular}




\begin{tabular}{|c|c|c|c|c|}
\hline & Adenium obesum ${ }^{*} E x$ & & $\operatorname{Im~L}$ & \\
\hline & Aganosma cymosa $^{* * I n}$ & & & \\
\hline & Allamanda cathartica ${ }^{E x}$ & & & \\
\hline & Anodendron paniculatum ${ }^{* *} I n$ & & & \\
\hline & Asclepias curassavica ${ }^{* * E x}$ & & & \\
\hline & Carissa spinarum ${ }^{* *} I n$ & & & \\
\hline & Cryptolepis dubia ${ }^{*} \operatorname{In}$ & & & \\
\hline & Gomphocarpus physocarpus ${ }^{\text {Ex }}$ & & & \\
\hline & Hemidesmus indicus ${ }^{* I n}$ & & & \\
\hline & Ichnocarpus frutescens ${ }^{*}$ In & Apocynaceae & $\mathrm{L}$ & \\
\hline & Leptadenia reticulata $^{* * I n}$ & & & \\
\hline & Mandevilla boliviensis ${ }^{* *} E x$ & & & PC: S.Gunasena \\
\hline & Nerium oleander ${ }^{*} E x$ & & & \\
\hline & Ochrosia oppositifolia ${ }^{* I n}$ & & & \\
\hline Euploea core asela & Parsonsia alboflavescens ${ }^{*}$ In & & & \\
\hline & Pentalinon luteum ${ }^{* * E x}$ & & & \\
\hline & Pentatropis capensis ${ }^{* I n}$ & & & \\
\hline & Plumeria rubra ${ }^{E x}$ & & & found only ovipositing \\
\hline & Ficus arnottiana ${ }^{* * I n}$ & & $\mathrm{~L}$ & \\
\hline & Ficus benghalensis ${ }^{* *}$ In & & $\operatorname{Im~L}$ & \\
\hline & Ficus benjamina ${ }^{* E x}$ & & & \\
\hline & Ficus exasperata ${ }^{* *} I n$ & & & PC: L. Aberathne \\
\hline & Ficus microcarpa $^{* * I n}$ & & & \\
\hline & Ficus nervosa ${ }^{* *} \operatorname{In}$ & Moraceae & & \\
\hline & Ficus pumila $^{E x}$ & & $\mathrm{~L}$ & \\
\hline & Ficus racemosa ${ }^{* * I n}$ & & & \\
\hline & Ficus religiosa ${ }^{*}$ Ex & & & \\
\hline & Ficus tinctoria $^{* * I n}$ & & & \\
\hline & Streblus asper ${ }^{* *}$ In & & & \\
\hline Euploea sylvester montana & Gymnema sylvestre $^{\text {In }}$ & Apocynaceae & $\mathrm{L}$ & \\
\hline Euploea phaenareta corus & Cerbera odollam ${ }^{*}$ In & Apocynaceae & $\mathrm{L}$ & \\
\hline Euploea klugii sinhala & Streblus asper ${ }^{* I n}$ & Moraceae & $\mathrm{L}$ & \\
\hline & Tragia hispida ${ }^{* *} I n$ & & & \\
\hline Ariadne ariadne minorata & Tragia involucrata ${ }^{* * I n}$ & Euphorbiaceae & $\mathrm{L}$ & \\
\hline & Tragia plukenetii ${ }^{* *} \operatorname{In}$ & & & \\
\hline & Tragia hispida ${ }^{* * I n}$ & & & \\
\hline Arladne merlone taprobana & Tragia involucrata ${ }^{* * I n}$ & Euphorbiaceae & $\mathrm{L}$ & \\
\hline Byblia ilithyia & Tragia plukenetii ${ }^{* *} \operatorname{In}$ & Euphorbiaceae & $\mathrm{L}$ & \\
\hline & Flacourtia indica ${ }^{* *} \operatorname{In}$ & & & \\
\hline Cupha erymanthis placida & Homalium ceylanicum $^{* *}{ }^{* n}$ & Salicaceae & $\mathrm{L}$ & \\
\hline & Scolopia acuminata ${ }^{* * I n}$ & & $\mathrm{Im} \mathrm{L}$ & \\
\hline & Hydnocarpus venenata ${ }^{* * E n}$ & Achariaceae & & \\
\hline & Dovyalis hebecarpa ${ }^{* * E n}$ & & $\mathrm{~L}$ & \\
\hline Phalanta phalantha phalantha & Flacourtia indica $^{* * \ln }$ & Salicaceae & & \\
\hline & Flacourtia jangomas ${ }^{* *} E x$ & salicaceae & & \\
\hline & Scolopia acuminata ${ }^{* *} I n$ & & $\operatorname{Im} \mathrm{L}$ & \\
\hline Phalanta alcippe ceylonica & Rinorea decora ${ }^{* * E n}$ & Violaceae & $\mathrm{L}$ & PC: v. Pootern \\
\hline Cirrochroa thais lanka & Hydnocarpus venenata ${ }^{* *}$ En & Achariaceae & $\mathrm{L}$ & \\
\hline Cethosia nietneri nietneri & Adenia hondala ${ }^{* * I n}$ & Passifloraceae & $\mathrm{L}$ & \\
\hline & Viola betonicifolia $^{* I n}$ & & & \\
\hline Argynnis hyperbius taprobana & Viola pilosa ${ }^{* * *} / n$ & Violaceae & $\mathrm{L}$ & \\
\hline Vanesca indica nuhicola & Girardinia diversifolia $^{* *}$ In & Urticaceae & $\mathrm{I}$ & \\
\hline Vanessa ınaıca nublcola & Urtica urens ${ }^{* *}$ Ex & Urticaceae & $\mathrm{L}$ & \\
\hline Vanessa cardui & Anaphalis subdecurrens ${ }^{*}$ In & Asteraceae & $\mathrm{L}$ & \\
\hline Kaniska canace haronica & Smilax perfoliata ${ }^{* *}$ In & Smilacaceae & $\mathrm{I}$ & \\
\hline Kanıska canace haronica & Smilax zeylanica ${ }^{* * I n}$ & Smilacaceae & $\mathrm{L}$ & \\
\hline Iunonia lemonias vaisva & Barleria prionitis $^{* *}{ }^{\prime \prime n}$ & Acanthaceae & $\mathrm{L}$ & \\
\hline Junonia lemonias vaisya & Hygrophila auriculata ${ }^{* *} \operatorname{In}$ & Acantnaceae & L & \\
\hline
\end{tabular}




\begin{tabular}{|c|c|c|c|c|}
\hline & Lindernia rotundifolia ${ }^{* * I n}$ & Linderniaceae & & \\
\hline \multirow{3}{*}{ Junonia orithya patenas } & Justicia procumbens ${ }^{* I n}$ & Acanthaceae & \multirow{3}{*}{$\mathrm{L}$} & \\
\hline & Lindernia pusilla ${ }^{* * I n}$ & Linderniaceae & & \\
\hline & Centranthera indica ${ }^{* * I n}$ & Orobanchceae & & only in the lab \\
\hline \multirow{5}{*}{ Junonia atlites } & Hygrophila auriculata ${ }^{* * I n}$ & Acanthaceae & \multirow{5}{*}{$\mathrm{L}$} & \\
\hline & Lindernia anagallis ${ }^{* * I n}$ & \multirow{4}{*}{ Linderniaceae } & & \\
\hline & Lindernia crustacea ${ }^{* * I n}$ & & & \\
\hline & Lindernia pusilla ${ }^{* * I n}$ & & & \\
\hline & Lindernia antipoda ${ }^{* * I n}$ & & & \\
\hline \multirow{6}{*}{ Junonia iphita pluviatilis } & Barleria prionitis ${ }^{* *}{ }^{\prime n}$ & \multirow{6}{*}{ Acanthaceae } & \multirow{6}{*}{$\mathrm{L}$} & \\
\hline & Ruellia patula ${ }^{* * I n}$ & & & \\
\hline & Ruellia prostrata $^{* * I n}$ & & & \\
\hline & Eranthemum capense ${ }^{* * I n}$ & & & \\
\hline & Phaulopsis imbricata ${ }^{* * I n}$ & & & \\
\hline & Strobilanthes diandra ${ }^{* * E n}$ & & & \\
\hline \multirow{5}{*}{ Junonia almana almana } & Hygrophila auriculata ${ }^{* *} / n$ & \multirow{2}{*}{ Acanthaceae } & \multirow{5}{*}{$\mathrm{L}$} & \\
\hline & Ruellia tuberosa $^{* * E x}$ & & & \\
\hline & Lindernia anagallis ${ }^{* *} I n$ & & & \\
\hline & Lindernia pusilla $^{* * I n}$ & Linderniaceae & & \\
\hline & Phyla nodiflora ${ }^{* * I n}$ & Verbenaceae & & PC: v. Pootern \\
\hline \multirow{5}{*}{ Hypolimnas bolina bolina } & Ageratum conyzoides ${ }^{* *}$ Ex & \multirow{2}{*}{ Asteraceae } & \multirow{5}{*}{$\mathrm{L}$} & \\
\hline & Synedrella nodiflora ${ }^{* *}$ Ex & & & \\
\hline & Sida cordata ${ }^{* * I n}$ & \multirow{3}{*}{ Malvaceae } & & \\
\hline & Sida rhombifolia ${ }^{* * I n}$ & & & only in the lab \\
\hline & Urena lobata ${ }^{* * I n}$ & & & \\
\hline \multirow{6}{*}{ Hypolimnas misippus } & Asystasia gangetica ${ }^{* * I n}$ & \multirow{5}{*}{ Acanthaceae } & \multirow{6}{*}{$\mathrm{L}$} & \\
\hline & Blepharis integrifolia $^{* * I n}$ & & & \\
\hline & Blepharis maderaspatensis $^{* *} I n$ & & & \\
\hline & Dyschoriste litoralis ${ }^{* *}$ In & & & \\
\hline & Ruellia tuberosa ${ }^{* * E x}$ & & & \\
\hline & Portulaca oleracea ${ }^{* * I n}$ & Portulacaceae & & \\
\hline & Asystasia chelonoides ${ }^{\text {In }}$ & & & \\
\hline Doleschallıa bisaltıde ceylonica & Pseuderanthemum latifolium ${ }^{* * I n}$ & Acanthaceae & L & \\
\hline Kallima nhilarchus & Strobilanthes diandra ${ }^{* *} E n$ & Acontboceoe & $\mathrm{J}$ & \\
\hline nauma pintarcrius & Strobilanthes lupulina ${ }^{* * 1 n}$ & Acantilacede & $\mathrm{L}$ & \\
\hline Pantonoria hordonia sinuata & Acacia caesia $^{* * \operatorname{In}}$ & Fahaceae & $\mathrm{L}$ & \\
\hline Pantoporıa hordonıa sinuata & Acacia pennata $^{* * I n}$ & Fabaceae & $\mathrm{L}$ & \\
\hline & Celtis philippensis ${ }^{* * I n}$ & & & \\
\hline & Celtis timorensis $^{* *} \ln$ & Cannabaceae & & \\
\hline & Trema orientalis ${ }^{* * I n}$ & & & \\
\hline & Aeschynomene americana ${ }^{* *} E x$ & & & \\
\hline & Arachis pintoi $^{* * E x}$ & & & \\
\hline & Bauhinia purpurea ${ }^{* * E x}$ & & & \\
\hline & Cassia fistula ${ }^{* *} E x$ & & & \\
\hline & Centrosema pubescens ${ }^{* *}$ Ex & & & \\
\hline & Clitoria ternatea $^{* * I n}$ & & & PC: R. Samanmalee \\
\hline & Codariocalyx motorius ${ }^{* * I n}$ & & & \\
\hline Neptis hylas varmona & Dalbergia pseudo-sissoo ${ }^{* * I n}$ & & $\mathrm{~L}$ & \\
\hline & Desmodium pryonii ${ }^{* *}$ In & Fabaceae & & \\
\hline & Pseudarthria viscida ${ }^{* * I n}$ & & & \\
\hline & Psophocarpus tetragonolobus ${ }^{* *}$ Ex & & & \\
\hline & Pueraria phaseoloides ${ }^{* * E x}$ & & & \\
\hline & Senna alata $^{* *} E x$ & & & \\
\hline & Vigna hosei $^{* *} E x$ & & & \\
\hline & Vigna unguiculata ${ }^{* *} E x$ & & & \\
\hline & Unidentified sp. & & & \\
\hline & Nothapodytes nimmoniana ${ }^{* *}$ In & Icacinaceae & & \\
\hline & Grewia bracteata $^{* *} I n$ & Malvaceae & & \\
\hline
\end{tabular}




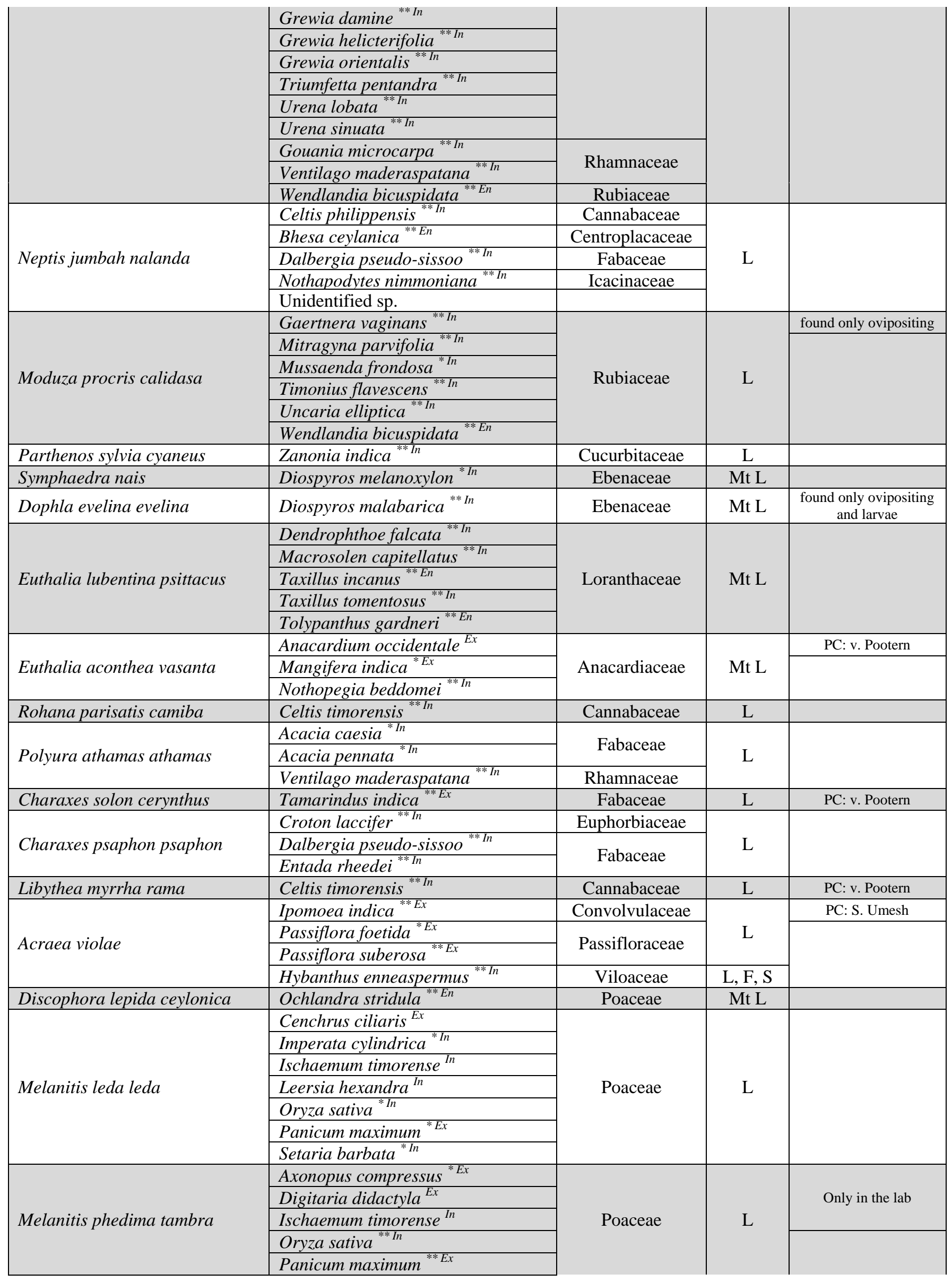




\begin{tabular}{|c|c|c|c|c|}
\hline & Setaria barbata ${ }^{* I n}$ & & & \\
\hline \multirow{4}{*}{ Lethe drypetis drypetis } & Bambusa multiplex ${ }^{*} E x$ & \multirow{4}{*}{ Poaceae } & \multirow{4}{*}{$\mathrm{L}$} & \\
\hline & Bambusa vulgaris ${ }^{*}$ In & & & Only in the lab \\
\hline & Davidsea attenuata ${ }^{* *} E n$ & & & \\
\hline & Dendrocalamus giganteus ${ }^{*} E x$ & & & \\
\hline Lethe daretis & Sinarundinaria debilis ${ }^{E n}$ & Poaceae & $\mathrm{L}$ & found only ovipositing \\
\hline \multirow{4}{*}{ Orsotriaena medus mandata } & Axonopus compressus ${ }^{*}$ Ex & \multirow{4}{*}{ Poaceae } & \multirow{4}{*}{$\mathrm{L}$} & \\
\hline & Leersia hexandra $^{\text {In }}$ & & & \\
\hline & Oryza sativa ${ }^{* I n}$ & & & \\
\hline & Panicum maximum $^{E x}$ & & & \\
\hline \multirow{2}{*}{ Mycalesis subdita } & Axonopus compressus ${ }^{\text {Ex }}$ & \multirow{2}{*}{ Poaceae } & \multirow{2}{*}{$\mathrm{L}$} & \multirow{2}{*}{ only in the lab } \\
\hline & Panicum maximum ${ }^{E x}$ & & & \\
\hline \multirow[b]{2}{*}{ Mycalesis mineus polydecta } & Axonopus compressus ${ }^{*}$ Ex & \multirow{2}{*}{ Poaceae } & \multirow[b]{2}{*}{$\mathrm{L}$} & \\
\hline & Panicum maximum ${ }^{* E x}$ & & & \\
\hline \multirow{4}{*}{ Mycalesis perseus typhlus } & Axonopus compressus ${ }^{*}$ Ex & \multirow{4}{*}{ Poaceae } & \multirow{4}{*}{$\mathrm{L}$} & \\
\hline & Eleusine indica ${ }^{* * I n}$ & & & \\
\hline & Leersia hexandra $^{\text {In }}$ & & & \\
\hline & Oryza sativa ${ }^{* I n}$ & & & \\
\hline \multirow{3}{*}{ Mycalesis patnia patnia } & Cyrtococcum trigonum ${ }^{*}$ In & \multirow{3}{*}{ Poaceae } & & \\
\hline & Isachne globosa ${ }^{* I n}$ & & $\mathrm{~L}$ & \\
\hline & Unidentified sp. & & & \\
\hline & Axonopus compressus ${ }^{*}$ Ex & & & \\
\hline Ypthima ceylonica & Cyrtococcum trigonum $^{\text {In }}$ & Poaceae & $\mathrm{L}$ & \\
\hline & Unidentified sp. & & & \\
\hline Ypthima singala & Axonopus compressus ${ }^{*}$ Ex & Poaceae & $\mathrm{L}$ & only in the lab \\
\hline & Areca catech ${ }^{*}{ }^{* I n}$ & & & \\
\hline & Borassus flabellifer $^{* *} E x$ & & & \\
\hline & Calamus rotang ${ }^{* * I n}$ & & & \\
\hline & Calamus thwaitesii $^{*}$ In & & & \\
\hline & Caryota urens ${ }^{* I n}$ & & & \\
\hline Elymnias hypermnestra fraterna & Cocos nucifera ${ }^{*}$ In & Arecaceae & $\mathrm{L}$ & \\
\hline & Cyrtostachys renda ${ }^{E x}$ & & & \\
\hline & Dypsis lutescens ${ }^{*} E x$ & & & \\
\hline & Phoenix pusilla ${ }^{* I n}$ & & & \\
\hline & Rhapis excelsa ${ }^{*} \mathrm{Ex}$ & & & \\
\hline & Saribus rotundifolius ${ }^{*} E x$ & & & PC: S. Mindika \\
\hline & Calamus ovoideus ${ }^{* * I n}$ & & & \\
\hline Elymnias singhala & Caryota urens ${ }^{* / n}$ & Arecaceae & $\mathrm{L}$ & \\
\hline & Loxococcus rupicola $^{* I n}$ & & & \\
\hline & $\begin{array}{l}\text { Lycaenid } \\
\end{array}$ & & & \\
\hline & Entada rheedei ${ }^{*}:{ }^{\prime} n$ & & & \\
\hline & Indigofera tinctoria ${ }^{* * I n}$ & & & \\
\hline & Pericopsis mooniana ${ }^{* *} / n$ & Fabaceae & & \\
\hline Curetis thetis & Millettia pinnata $^{* / n}$ & & $\operatorname{lm} \mathrm{L}$ & \\
\hline & Pterocarpus indicus ${ }^{* * E x}$ & & & \\
\hline & Lepisanthes tetraphylla ${ }^{* *}$ In & Sapindaceae & & \\
\hline Arhopala abseus mackwoodi & Vateria copallifera ${ }^{* E n}$ & Dipterocarpaceae & $\operatorname{Im~L}$ & \\
\hline & Terminalia arjuna ${ }^{* * 1 n}$ & & & \\
\hline A rhonala amantes amantes & Terminalia catappa $^{*}{ }^{E x}$ & Combretaceae & & \\
\hline Arhopala amantes amantes & Terminalia chebula $^{\text {In }}$ & & $\mathrm{L}$ & \\
\hline & Syzygium cumini $^{\text {In }}$ & Myrtaceae & & \\
\hline Arhopala ormistoni & Vateria copallifera ${ }^{* E n}$ & Dipterocarpaceae & $\operatorname{Im~L}$ & \\
\hline & Terminalia arjuna $^{* * 1 n}$ & Combretaceae & $\mathrm{L}$ & \\
\hline & Vateria copallifera $^{* * n}$ & Dipterocarpaceae & $\operatorname{Im~L}$ & \\
\hline & Elaeocarpus serratus ${ }^{* I n}$ & Elaeocarpaceae & & \\
\hline Arhopala centaurus pirama & Psidium guajava ${ }^{* * E x}$ & Murtacene & $\mathrm{I}$ & PC: D. Danushka \\
\hline & Syzygium cumini ${ }^{* I n}$ & Myrtaceae & $\mathrm{L}$ & \\
\hline & Lepisanthes tetraphylla ${ }^{\text {In }}$ & Sapindaceae & & \\
\hline
\end{tabular}




\begin{tabular}{|c|c|c|c|c|}
\hline \multirow{5}{*}{ Surendra quercetorum discalis } & 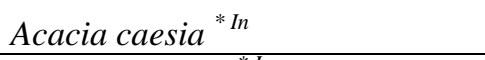 & \multirow{5}{*}{ Fabaceae } & \multirow{5}{*}{$\mathrm{L}$} & \\
\hline & Acacia pennata $^{*} / n$ & & & \\
\hline & Albizia lebbeck ${ }^{* * I n}$ & & & \\
\hline & Falcataria moluccana $^{* *} E x$ & & & \\
\hline & Calliandra surinamensis ${ }^{*}$ Ex & & & \\
\hline \multirow{5}{*}{ Zesius chrysomallus } & Terminalia arjuna ${ }^{* *} I n$ & \multirow{2}{*}{ Combretaceae } & \multirow{5}{*}{$\mathrm{L}$} & \\
\hline & Terminalia catappa ${ }^{* * E x}$ & & & \\
\hline & Cassia fistula ${ }^{* * E x}$ & \multirow{2}{*}{ Fabaceae } & & \\
\hline & Falcataria moluccana ${ }^{* *} E x$ & & & \\
\hline & Psidium guajava ${ }^{* E x}$ & Myrtaceae & & PC: D. Danushka \\
\hline Amblypodia anita naradoides & Olax scandens ${ }^{* * \operatorname{In}}$ & Olacaceae & $\mathrm{L}$ & \\
\hline \multirow{7}{*}{ Iraota timoleon nicevillei } & Ficus arnottiana ${ }^{* * I n}$ & \multirow{7}{*}{ Moraceae } & \multirow{7}{*}{$\mathrm{F}$} & \\
\hline & Ficus benghalensis ${ }^{* *}$ In & & & \\
\hline & Ficus drupacea ${ }^{* * / n}$ & & & \\
\hline & Ficus microcarpa ${ }^{* *} I n$ & & & \\
\hline & Ficus racemosa ${ }^{* *} \operatorname{In}$ & & & \\
\hline & Ficus religiosa ${ }^{*} E x$ & & & \\
\hline & Ficus tsjahela $^{* *} \operatorname{In}$ & & & \\
\hline Catapaecilma major myosotina & Psidium guajava ${ }^{* * E x}$ & Myrtaceae & $\mathrm{L}$ & \\
\hline \multirow{3}{*}{ Loxura atymnus arcuata } & Dioscorea alata ${ }^{* *} E x$ & Dioscoreaceae & \multirow{3}{*}{$\operatorname{Im} \mathrm{L}$} & PC: H. Kularathne \\
\hline & Smilax perfoliata ${ }^{* * I n}$ & \multirow{2}{*}{ Smilacaceae } & & \\
\hline & Smilax zeylanica ${ }^{* *} \operatorname{In}$ & & & \\
\hline \multirow{7}{*}{ Rathinda amor } & Dimorphocalyx glabellus ${ }^{* *} I n$ & \multirow{2}{*}{ Euphorbiaceae } & \multirow{3}{*}{$\operatorname{Im~L~}$} & \\
\hline & Mischodon zeylanicus ${ }^{* *}{ }^{\prime n}$ & & & \\
\hline & Gomphia serrata $^{* * 1 n}$ & Ochnaceae & & \\
\hline & Ixora coccinea $^{* * 1 n}$ & \multirow{3}{*}{ Rubiaceae } & $\mathrm{F}$ & \\
\hline & Ixora macrothyrsa ${ }^{* * E x}$ & & $\mathrm{~F}$ & \\
\hline & Ixora pavetta $^{* * \operatorname{In}}$ & & $\operatorname{Im} \mathrm{I}$ & \\
\hline & Lepisanthes tetraphylla ${ }^{* *} I n$ & Sapindaceae & $\mathrm{Im} \mathrm{L}$ & \\
\hline \multirow{2}{*}{ Cheritra freja pseudojafra } & Entada rheedei ${ }^{* * \operatorname{In}}$ & Fabaceae & $\operatorname{Im} \mathrm{I}$ & \\
\hline & Cinnamomum verum ${ }^{* * I n}$ & Lauraceae & $\mathrm{Im} \mathrm{L}$ & PC: I. Harshajith \\
\hline & Senna auriculata ${ }^{* * \operatorname{In}}$ & Fabaceae & & PC: v.Pootern \\
\hline Spındasis vulcanus fusca & Cardiospermum halicacabum ${ }^{*}$ In & Sapindaceae & $\mathrm{L}$ & \\
\hline & Acacia eburnea ${ }^{* I n}$ & & & \\
\hline Spindasis ictis ceylonica & Senna auriculata ${ }^{* * I n}$ & Fabaceae & $\mathrm{L}$ & \\
\hline & Senna surattensis ${ }^{* *}$ Ex & & & only in the lab \\
\hline Spindasis elima fairliei & Acacia eburnea $^{\text {In }}$ & Fabaceae & $\mathrm{L}$ & \\
\hline & Dendrophthoe falcata ${ }^{* I n}$ & & & \\
\hline Tajuria cippus longinus & Dendrophthoe ligulata ${ }^{* *}$ En & Loranthaceae & $\operatorname{Im} \mathrm{L}$ & \\
\hline & Taxillus cuneatus ${ }^{* I n}$ & & & \\
\hline & Dendrophthoe falcata ${ }^{* / n}$ & & & \\
\hline Tajuria jehana ceylanica & Dendrophthoe ligulata ${ }^{* * E n}$ & Loranthaceae & $\operatorname{Im} \mathrm{L}$ & \\
\hline & Scurrula parasitica ${ }^{* * I n}$ & & & \\
\hline & Scurrula cordifolia ${ }^{* E n}$ & & & \\
\hline Pratapa deva deva & Taxillus tomentosus ${ }^{*}$ In & Loranthaceae & $\operatorname{Im~L~}$ & \\
\hline & Arachnis flos-aeris ${ }^{E x}$ & & $\mathrm{R}$ & \\
\hline & Arundina graminifolia ${ }^{* E x}$ & & & \\
\hline & Cymbidium aloifolium ${ }^{* * I n}$ & & $\mathrm{~F}$ & Only in the lab \\
\hline & Luisia sp. ${ }^{* *}$ & & & \\
\hline Hypolycaena nilgirica & Malaxis versicolor ${ }^{* I n}$ & Orchidaceae & I & \\
\hline & Peristylus trimenii $^{*}$ En & & $\mathrm{F}$ & \\
\hline & Spathoglottis plicata $^{* E x}$ & & $\mathrm{~F}, \mathrm{R}$ & \\
\hline & Vanda tessellata ${ }^{* I n}$ & & E $\mathbf{P}$ & \\
\hline & Vanda testacea $^{\text {In }}$ & & $\mathrm{F}, \mathrm{R}$ & \\
\hline Bind ahara nhosider & Salacia chinensis ${ }^{* *} \operatorname{In}$ & & & only in the lab \\
\hline Bindahara phocides & Salacia reticulata ${ }^{* / n}$ & Celastraceae & Fruit & \\
\hline Virachola perse ghela & Catunaregam spinosa ${ }^{I n}$ & Rubiaceae & Fruit & \\
\hline Virachola isocrates & Catunaregam spinosa ${ }^{* *} I n$ & Rubiaceae & Fruit & \\
\hline
\end{tabular}




\begin{tabular}{|c|c|c|c|c|}
\hline & Limonia acidissima ${ }^{* I n}$ & Rutaceae & & \\
\hline \multirow{4}{*}{ Rapala manea schistacea } & Cassia roxburghii **In & Fabaceae & $\mathrm{L}$ & \\
\hline & Urena lobata $^{* * 1 n}$ & Malvaceae & $\mathrm{F}$ & PC: v. Pootern \\
\hline & Ziziphus mauritiana $^{* * I n}$ & Rhamnaceae & $\mathrm{L}$ & \\
\hline & Gnidia glauca ${ }^{* *}{ }^{\prime \prime n}$ & Thymelaeaceae & Im L & found only ovipositing \\
\hline Rapala varuna lazulina & Ziziphus oenopolia $^{* * I n}$ & Rhamnaceae & $\mathrm{L}$ & PC: T. Ranasinghe \\
\hline Deudorix epijarbas epijarbas & Cardiospermum halicacabum ${ }^{* * I n}$ & Sapindaceae & Seeds & \\
\hline Anthene lycaenina lycaenina & Lepisanthes tetraphylla ${ }^{* *}$ In & Sapindaceae & $\operatorname{Im~L}$ & \\
\hline Nacaduba hermus sidoma & Symplocos cochinchinensis ${ }^{* I n}$ & Symplocaceae & $\operatorname{Im~L}$ & \\
\hline Nacaduba berenice ormistoni & Lepisanthes tetraphylla ${ }^{*} / \mathrm{In}$ & Sapindaceae & $\operatorname{Im~L}$ & \\
\hline Nacaduba sinhala & Dimocarpus longan ${ }^{* I n}$ & Sapindaceae & Im L & \\
\hline Nacaduba kurava prominens & Ardisia missionis $^{* *}{ }^{\prime \prime}$ & Primulaceae & $\mathrm{F}$ & found only ovipositing \\
\hline Nacaduba calauria evansi & Vateria copallifera $^{* * E n}$ & Dipterocarpaceae & $\operatorname{Im~L}$ & \\
\hline \multirow{13}{*}{ Prosotas nora ardates } & Sambucus javanica ${ }^{* *} E x$ & Adoxaceae & \multirow{13}{*}{$\mathrm{F}$} & found only ovipositing \\
\hline & Terminalia catappa ${ }^{*} E x$ & Combretaceae & & \\
\hline & ${\text { Acacia } \text { caesia }^{\text {In }}}^{\text {In }}$ & \multirow{5}{*}{ Fabaceae } & & \\
\hline & Acacia pennata ${ }^{I n}$ & & & \\
\hline & Bauhinia racemosa ${ }^{* * I n}$ & & & \\
\hline & Derris scandens $^{\text {In }}$ & & & \\
\hline & Pithecellobium dulce ${ }^{* E x}$ & & & \\
\hline & Croton aromaticus ${ }^{* I n}$ & Euphorbiaceae & & \\
\hline & Calliandra calothyrsus ${ }^{* * E x}$ & \multirow{3}{*}{ Fabaceae } & & \\
\hline & Calliandra surinamensis ${ }^{* *} E x$ & & & \\
\hline & Samanea saman ${ }^{*} E x$ & & & \\
\hline & Murraya koenigii ${ }^{* * 1 n}$ & Rutaceae & & \\
\hline & Allophylus cobbe ${ }^{* / n}$ & Sapindaceae & & \\
\hline \multirow{3}{*}{ Prosotas dubiosa indica } & Albizia odoratissima $^{\text {In }}$ & & \multirow{3}{*}{$\mathrm{F}$} & \\
\hline & Pithecellobium dulce ${ }^{* * E x}$ & Fabaceae & & \\
\hline & Samanea saman ${ }^{* E x}$ & Fabaceae & & \\
\hline \multirow{20}{*}{ Jamides bochus bochus } & Acacia auriculiformis ${ }^{E x}$ & \multirow{20}{*}{ Fabaceae } & \multirow{20}{*}{$\mathrm{F}$} & \\
\hline & Cajanus cajan $^{E x}$ & & & \\
\hline & Canavalia cathartica ${ }^{* *} I n$ & & & \\
\hline & Clitoria ternatea $^{* * I n}$ & & & PC: D. Danushka \\
\hline & Crotalaria micans $^{* *} E x$ & & & \\
\hline & Derris scandens ${ }^{\text {In }}$ & & & \\
\hline & Flemingia macrophylla ${ }^{* * I n}$ & & & \\
\hline & Gliricidia sepium ${ }^{* E x}$ & & & \\
\hline & Lablab purpureus ${ }^{* *} E x$ & & & \\
\hline & Macrotyloma uniflorum ${ }^{* * I n}$ & & & \\
\hline & Paraderris elliptica ${ }^{E x}$ & & & \\
\hline & Phaseolus vulgaris ${ }^{* * E x}$ & & & \\
\hline & Millettia pinnata $^{\text {In }}$ & & & \\
\hline & Pterocarpus indicus ${ }^{E x}$ & & & \\
\hline & Pueraria phaseoloides ${ }^{*} E x$ & & & \\
\hline & Sesbania grandiflora ${ }^{* * E x}$ & & & PC: R. Samanmalee \\
\hline & Tephrosia candida ${ }^{E x}$ & & & \\
\hline & Tephrosia vogelii ${ }^{\text {Ex }}$ & & & \\
\hline & Vigna radiata ${ }^{E x}$ & & & \\
\hline & Vigna unguiculata ${ }^{*} E x$ & & & \\
\hline Jamides coruscans & Humboldtia laurifolia ${ }^{* I n}$ & Fabaceae & $\operatorname{Im~L}$ & \\
\hline \multirow[b]{2}{*}{ Jamides lacteata } & Lepisanthes erecta $^{* I n}$ & \multirow[b]{2}{*}{ Sapindaceae } & \multirow[b]{2}{*}{$\operatorname{Im} \mathrm{L}$} & \\
\hline & $\begin{array}{l}\text { Lepisanthes tetraphylla var. } \\
\text { trichocarpa }{ }^{* * I n}\end{array}$ & & & \\
\hline \multirow{5}{*}{ Jamides alecto meilichius } & Alpinia calcarata $^{* E x}$ & \multirow{5}{*}{ Zingiberaceae } & \multirow{5}{*}{ F, seeds } & \\
\hline & Alpinia galanga ${ }^{* *} E x$ & & & \\
\hline & Alpinia purpurata ${ }^{*} E x$ & & & \\
\hline & Alpinia zerumbet ${ }^{* * E x}$ & & & \\
\hline & Amomum fulviceps ${ }^{* E n}$ & & & \\
\hline
\end{tabular}




\begin{tabular}{|c|c|c|c|c|}
\hline & Amomum trichostachyum ${ }^{\text {En }}$ & & & \\
\hline & Elettaria cardamomum ${ }^{* I n}$ & & & \\
\hline & Hedychium flavescens ${ }^{*}$ Ex & & & \\
\hline & Zingiber cylindricum $*^{\text {En }}$ & & & \\
\hline & Zingiber wightianum $*$ In & & & \\
\hline & Zingiber zerumbet ${ }^{* E x}$ & & & \\
\hline & Zingiber sp. & & & \\
\hline & Abrus precatorius ${ }^{* I n}$ & & & \\
\hline & Abrus pulchellus ${ }^{* * I n}$ & & $\mathrm{~F}$ & \\
\hline & Entada rheedei ${ }^{* * I n}$ & & $\operatorname{Im~L}$ & \\
\hline & Flemingia macrophylla ${ }^{* * I n}$ & & $\mathrm{~F}_{\mathrm{O}}$ & \\
\hline Jamides celeno tissama & Millettia pinnata ${ }^{* I n}$ & Fabaceae & $\mathrm{F}$ & \\
\hline & Phaseolus vulgaris ${ }^{*}$ Ex & & $\operatorname{Im~L}$ & \\
\hline & Pueraria phaseoloides ${ }^{*} E x$ & & & \\
\hline & Vigna hosei ${ }^{* *}$ Ex & & $\mathrm{F}$ & \\
\hline & Vigna unguiculata $^{*} E x$ & & & \\
\hline Catochrysops panormus & Pueraria phaseoloides ${ }^{*}$ Ex & & $\mathrm{F}_{\mathrm{H}}$ & \\
\hline panormus & Flemingia macrophylla $^{* * I n}$ & Fabaceae & $\mathrm{F}$ & \\
\hline & Phyllodium pulchellum ${ }^{* * I n}$ & & & \\
\hline & Rhynchosia cana ${ }^{* * I n}$ & & & \\
\hline Catochrysops strabo strabo & Tephrosia purpurea ${ }^{* * I n}$ & Fabaceae & $\mathrm{F}$ & \\
\hline & Tephrosia villosa ${ }^{* * I n}$ & & & \\
\hline & Cajanus trinervius ${ }^{* *}$ In & & & \\
\hline & Crotalaria incana ${ }^{* * E x}$ & & $\mathrm{~F}$ & \\
\hline & Crotalaria laburnifolia ${ }^{* *} / n$ & & & \\
\hline & Crotalaria micans ${ }^{* * E x}$ & & & \\
\hline Lampides boeticus & Crotalaria pallida ${ }^{* * I n}$ & Fabaceae & & \\
\hline & Crotalaria verrucosa $a^{* *} / n$ & & $\mathrm{~F}$, seeds & \\
\hline & Crotalaria trichotoma ${ }^{* *} \mathrm{Ex}$ & & & \\
\hline & Mundulea sericea ${ }^{* *} \operatorname{In}$ & & $\Gamma$ & \\
\hline & Ulex europaeus ${ }^{* *}$ Ex & & $\mathrm{F}$ & \\
\hline & Aeschynomene americana ${ }^{* *} E x$ & & & \\
\hline & Indigofera tinctoria ${ }^{* *} \operatorname{In}$ & Fabaceae & & \\
\hline Leptotes plinius plinius & Rhynchosia minima ${ }^{* * I n}$ & & $\mathrm{~F}$ & \\
\hline & Plumbago auriculata ${ }^{* *} E x$ & & & \\
\hline & Plumbago zeylanica $^{\text {In }}$ & Plumbaginaceae & & \\
\hline & Gouania microcarpa $^{* * I n}$ & & & \\
\hline & Ziziphus jujuba $^{* * E x}$ & & & PC: T. Ranasinghe \\
\hline Cactalius rociman rosimn & Ziziphus napeca ${ }^{* * E n}$ & Rhamnaceae & $\operatorname{Im} \mathrm{I}$ & \\
\hline Castalius rosimon rosimon & Ziziphus mauritiana $^{* * I n}$ & Rhamnaceae & $\operatorname{Im~L}$ & \\
\hline & Ziziphus xylopyrus ${ }^{* * E x}$ & & & found only ovipositing \\
\hline & Ziziphus oenopolia $^{* * I n}$ & & & \\
\hline Discolampa ethion ethion & Ziziphus oenopolia $^{* *} \operatorname{In}$ & Rhamnaceae & $\operatorname{Im~L}$ & \\
\hline & Gouania microcarpa $^{* * I n}$ & & & \\
\hline Caleta decidia & Ziziphus rugosa ${ }^{* *} I n$ & Rhamnaceae & $\operatorname{Im~L}$ & \\
\hline Tarucus callinara & Ziziphus mauritiana $^{* I n}$ & Rhamnaceae & $\operatorname{Im~L}$ & \\
\hline Танисис nare & Ziziphus mauritiana ${ }^{* I n}$ & Phomnoceop & $\operatorname{Im} \mathrm{I}$ & \\
\hline Iarucus nara & Ziziphus xylopyrus ${ }^{* *} E x$ & Knamnaceae & $\operatorname{ImL}$ & found only ovipositing \\
\hline & Indigofera linnaei ${ }^{* * I n}$ & & & \\
\hline Freyeria putli & Indigofera oblongifolia ${ }^{* *}$ In & Fabaceae & $\operatorname{Im~L}$ & \\
\hline & Indigofera tinctoria ${ }^{* * I n}$ & & & \\
\hline & Amaranthus viridis ${ }^{* *}{ }^{* *}$ & Amaranthaceae & $\operatorname{Im} \mathrm{L}$ & \\
\hline & Amaranthus spinosus ${ }^{* * I n}$ & Amaranthaceae & $\operatorname{lmL}$ & \\
\hline Zizeoria karcandra & Coldenia procumbens ${ }^{* * I n}$ & Boraginaceae & $I_{0}$ & \\
\hline Zizeeria karsandra & Sauropus bacciformis $^{* * I n}$ & Euphorbiaceae & $\mathrm{L}$ & \\
\hline & Glinus oppositifolius $^{* *}$ In & Molluginaceae & $\mathrm{F}, \mathrm{L}$ & \\
\hline & Tribulus terrestris ${ }^{* *}$ Ex & Zygophyllaceae & $\mathrm{L}$, fruits & \\
\hline Zizina otis indica & Desmodium heterophyllum ${ }^{* * *}$ & Fabaceae & F, Im L & \\
\hline
\end{tabular}




\begin{tabular}{|c|c|c|c|c|}
\hline & Desmodium triflorum ${ }^{* *}$ In & & & \\
\hline \multirow{3}{*}{ Zizula hylax hylax } & Ruellia patula $^{* * I n}$ & \multirow{3}{*}{ Acanthaceae } & & \\
\hline & Ruellia prostrata $^{* * I n}$ & & $\mathrm{~F}$ & \\
\hline & Ruellia tuberosa ${ }^{* *}$ Ex & & $\mathrm{F}$ & \\
\hline Talicada nyseus nyseus & Kalanchoe pinnata ${ }^{* * E x}$ & Crassulaceae & $\mathrm{L}$ & \\
\hline \multirow{3}{*}{ Everes lacturnus lacturnus } & Desmodium heterocarpon ${ }^{* *}$ In & \multirow{3}{*}{ Fabaceae } & \multirow{3}{*}{ Seeds } & \\
\hline & Desmodium triflorum ${ }^{* * 1 n}$ & & & \\
\hline & Desmodium uncinatum ${ }^{* *} E x$ & & & \\
\hline Azanus ubaldus & Acacia eburnea $^{* * I n}$ & Fabaceae & $\mathrm{F}$ & \\
\hline Azanus jesous gamra & Dichrostachys cinerea ${ }^{* * * 1 n}$ & Fabaceae & $\operatorname{Im~L}$ & \\
\hline \multirow{9}{*}{ Acytolepis puspa felderi } & Peltophorum pterocarpum ${ }^{* *}$ In & Fabaceae & \multirow{9}{*}{$\operatorname{Im~L}$} & PC: D. Danushka \\
\hline & Hiptage benghalensis ${ }^{*}{ }^{\prime \prime n}$ & Malpighiaceae & & \\
\hline & Bridelia moonii $^{* *}$ En & Phyllanthaceae & & \\
\hline & Bridelia retusa ${ }^{* * I n}$ & Pnyllantnaceae & & \\
\hline & Meliosma simplicifolia ${ }^{* *} \operatorname{In}$ & Sabiaceae & & \\
\hline & Lepisanthes tetraphylla ${ }^{* * I n}$ & \multirow{3}{*}{ Sapindaceae } & & \\
\hline & Nephelium lappaceum ${ }^{* *}$ Ex & & & \\
\hline & Sapindus emarginatus ${ }^{* *}$ In & & & \\
\hline & Schleichera oleosa ${ }^{* * I n}$ & Sapotaceae & & \\
\hline Udara lanka & Persicaria chinensis ${ }^{* * I n}$ & Polygonaceae & $\mathrm{F}$ & \\
\hline \multirow{3}{*}{ Neopithicops zalmora dharma } & Atalantia ceylanica $^{* * I n}$ & \multirow{3}{*}{ Rutaceae } & \multirow{3}{*}{$\operatorname{Im~L}$} & \\
\hline & Glycosmis angustifolia ${ }^{* *} I n$ & & & \\
\hline & Glycosmis pentaphylla ${ }^{* *} I n$ & & & \\
\hline \multirow{2}{*}{ Megisba malaya thwaitesi } & Mallotus philippensis ${ }^{* *}$ In & Euphorbiaceae & \multirow{2}{*}{$\mathrm{F}$} & \\
\hline & Allophylus cobbe ${ }^{* * I n}$ & Sapindaceae & & \\
\hline \multirow{5}{*}{ Euchrysops cnejus cnejus } & Macroptilium lathyroides ${ }^{* * E x}$ & \multirow{5}{*}{ Fabaceae } & Seeds & \\
\hline & Pueraria phaseoloides ${ }^{* *} E x$ & & \multirow{4}{*}{$\mathrm{F}$} & \\
\hline & Vigna marina $^{* * I n}$ & & & \\
\hline & Vigna trilobata ${ }^{* * 1 n}$ & & & \\
\hline & Vigna unguiculata ${ }^{*} E x$ & & & \\
\hline \multirow{2}{*}{ Chilades pandava lanka } & Cycas nathorstii ${ }^{* I n}$ & \multirow{2}{*}{ Cycadaceae } & & \\
\hline & Cycas revoluta ${ }^{* E x}$ & & $\operatorname{lm~L}$ & \\
\hline & Atalantia ceylanica ${ }^{* I n}$ & & & \\
\hline & Atalantia monophylla ${ }^{\text {In }}$ & & & \\
\hline Chilades lajus lajus & Citrus aurantifolia $^{E x}$ & Rutaceae & Im L & \\
\hline & Citrus sinensis $^{* *} E x$ & & & \\
\hline & Limonia acidissima $^{* I n}$ & & & \\
\hline & Acacia eburnea $^{* 1 n}$ & & & \\
\hline Chilades parrhasius nila & Acacia leucophloea ${ }^{* I n}$ & Fabaceae & $\operatorname{Im~L}$ & \\
\hline & Acacia planifrons ${ }^{* * I n}$ & & & \\
\hline & $\begin{aligned} \text { Riodinidae } \\
\end{aligned}$ & & & \\
\hline Ahisara echerius nrunos & Embelia ribes ${ }^{* * * 1 n}$ & Primulaceae & $\operatorname{Im} \mathrm{I}$ & \\
\hline 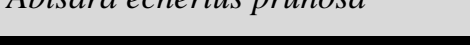 & Embelia tsjeriam-cottam ${ }^{*}$ n & 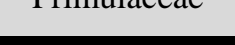 & (III & \\
\hline & $\begin{aligned} \text { Hesperiidae } \\
\end{aligned}$ & & & \\
\hline Burara oedipodea ataphus & Hiptage benghalensis ${ }^{*}+\frac{n}{n}$ & Malpighiaceae & $\operatorname{Im~L}$ & \\
\hline Bibasis sena sena & Hiptage benghalensis ${ }^{* *}{ }^{\prime} n$ & Malpighiaceae & $\operatorname{Im~L}$ & \\
\hline Badamia exclamationis & Terminalia bellirica $^{* *}{ }^{*} n$ & Combretaceae & $\operatorname{Im} \mathrm{I}$ & PC: v. Pootern \\
\hline 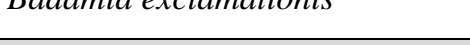 & Hiptage benghalensis ${ }^{* * / n}$ & Malpighiaceae & $111 \mathrm{~L}$ & \\
\hline Choaspes benjaminii benjaminii & Meliosma pinnata ${ }^{* I n}$ & Sabiaceae & $\mathrm{L}$ & \\
\hline & Calamus ovoideus $^{* *}$ En & & & \\
\hline Ganoara thursis clothilda & Calamus pseudotenuis $^{* * I n}$ & Arecaceae & $\mathrm{L}$ & \\
\hline Gangara thyrsis clothilda & Calamus rotang ${ }^{*}$ In & Arecaceae & $\mathrm{L}$ & \\
\hline & Calamus thwaitesii $^{* * I n}$ & & & \\
\hline Н sоra chromus chromus & Derris scandens ${ }^{* * I n}$ & Fahaceae & Im L & \\
\hline пазога спromus chromus & Millettia pinnata ${ }^{* I n}$ & Fadacede & $\mathrm{L}$ & \\
\hline Hasora taminatus taminatus & Derris parviflora ${ }^{* *}$ En & Fabaceae & $\operatorname{Im~L}$ & \\
\hline Celaenorrhinus spilothvrus & Gymnostachyum sanguinolentum ${ }^{* * E n}$ & Acanthaceae & $\mathrm{L}$ & \\
\hline & Strobilanthes diandra ${ }^{* * E n}$ & & & \\
\hline
\end{tabular}




\begin{tabular}{|c|c|c|c|c|}
\hline & Strobilanthes lupulina ${ }^{* *}{ }^{\prime n}$ & & & \\
\hline & Strobilanthes rhamnifolia ${ }^{* *}$ En & & & \\
\hline & Strobilanthes vestita ${ }^{* * E n}$ & & & \\
\hline & Strobilanthe sp. 1 & & & \\
\hline & Strobilanthes sp. 2 & & & \\
\hline & Mallotus sp. & & & \\
\hline & Unidentified sp. & Euphorbiaceae & & \\
\hline & Pterospermum suberifolium ${ }^{* *}$ In & & & \\
\hline & Berrya cordifolia ${ }^{* *}$ In & & & \\
\hline & Grewia damine $^{* * I n}$ & & & \\
\hline Coladenia indrani tissa & Grewia helicterifolia $^{* * I n}$ & Malvaceae & $\mathrm{L}$ & \\
\hline & Grewia orientalis $^{* *}$ In & & & \\
\hline & Microcos paniculata ${ }^{* * I n}$ & & & \\
\hline & Streblus asper ${ }^{* * I n}$ & Moraceae & & \\
\hline & Bridelia retusa $^{* * I n}$ & Phyllanthaceae & & \\
\hline & Lepidagathis fasciculata ${ }^{* * I n}$ & & & \\
\hline Sarangesa dasahara albicilıa & Lepidagathis walkeriana ${ }^{* * E n}$ & Acanthaceae & $\mathrm{L}$ & PC: v. Pootern \\
\hline Tapena thwaitesi thwaitesi & Dalbergia pseudo-sissoo ${ }^{* * I n}$ & Fabaceae & $\operatorname{Im~L}$ & \\
\hline & Dioscorea alata ${ }^{* * E x}$ & & & \\
\hline & Dioscorea bulbifera ${ }^{* *}$ In & & & PC: R. Samanmalee \\
\hline Tagiades japetus obscurus & Dioscorea oppositifolia ${ }^{* * I n}$ & Dioscoreaceae & $\mathrm{L}$ & \\
\hline & Dioscorea pentaphylla ${ }^{* * 1 n}$ & & & \\
\hline & Dioscorea tomentosa ${ }^{* * I n}$ & & & \\
\hline & Dioscorea alata ${ }^{* * E x}$ & & $\mathrm{~L}$ & \\
\hline & Dioscorea koyamae ${ }^{* *} E n$ & Disccoreaceae & Im L & \\
\hline Tagıades litıglosa ceylonica & Dioscorea oppositifolia ${ }^{*} / n$ & Dioscoreaceae & $\mathrm{L}$ & \\
\hline & Dioscorea spicata $^{* * I n}$ & & $\operatorname{Im~L}$ & \\
\hline & Grewia hirsuta ${ }^{* * I n}$ & & & \\
\hline Caprona ransonnettıl & Grewia damine ${ }^{* * I n}$ & Malvaceae & $\mathrm{L}$ & \\
\hline & Urena lobata $^{* * I n}$ & & & \\
\hline Gomalia elma albofasciata & Abutilon hirtum ${ }^{* * I n}$ & Malvaceae & $\mathrm{L}$ & \\
\hline & Garnotia exaristata $^{* * I n}$ & Роласеае & $\mathrm{I}$ & \\
\hline Baracus vittatus & Unidentified sp. & Poaceae & $\mathrm{L}$ & \\
\hline Ampittia dioscorides singa & Oryza sativa ${ }^{* * 1 n}$ & Poaceae & $\mathrm{L}$ & \\
\hline Halpe ceylonica & Bambusa vulgaris ${ }^{* * I n}$ & Poaceae & $\mathrm{L}$ & \\
\hline & Borassus flabellifer ${ }^{* *}$ Ex & & & \\
\hline & Caryota urens ${ }^{* * I n}$ & & & PC: S. Gunasena \\
\hline & Cocos nucifera ${ }^{* * I n}$ & & & \\
\hline Suastus gremius subgrisea & Corypha umbraculifera ${ }^{* *} E x$ & Arecaceae & $\mathrm{L}$ & \\
\hline & Cyrtostachys renda ${ }^{* * E x}$ & & & PC: S. Gunasena \\
\hline & Phoenix pusilla ${ }^{* * I n}$ & & & \\
\hline & Saribus rotundifolius ${ }^{* *} E x$ & & & \\
\hline Sugstus minuta minuta & Calamus pseudotenuis ${ }^{* * I n}$ & Arecaceae & $\mathrm{I}$ & \\
\hline suastus mтnиа типита & Loxococcos rupicola ${ }^{* *}$ En & Arecaceat & L & \\
\hline & Axonopus compressus ${ }^{* *}$ Ex & & & \\
\hline Iambrix salsala luteipalpis & Ochlandra stridula ${ }^{* * E n}$ & Poaceae & $\mathrm{L}$ & PC: R. Samanmalee \\
\hline & Oryza sativa ${ }^{* * I n}$ & & & \\
\hline & Curcuma longa ${ }^{* *} E x$ & & & \\
\hline & Curcuma oligantha ${ }^{* * E n}$ & & & \\
\hline Udacnes foluc & Curcuma zedoaria ${ }^{* *}$ Ex & 7ingiberacene & $\mathrm{I}$ & \\
\hline Ualaspes folus & Hedychium coronarium ${ }^{* *} E x$ & Zingiberaceae & $\mathrm{L}$ & \\
\hline & Kaempferia galanga ${ }^{* * E x}$ & & & \\
\hline & Zingiber officinale ${ }^{* *} E x$ & & & \\
\hline & Costus speciosus ${ }^{* * I n}$ & Costaceae & & \\
\hline & Alpinia purpurata ${ }^{* *} E x$ & & & \\
\hline Notocrypta paralysos alysia & Alpinia zerumbet ${ }^{* * E x}$ & Zinoiheraceae & $\mathrm{L}$ & \\
\hline & Curcuma longa ${ }^{* *} E x$ & Eingiveractac & & \\
\hline & Curcuma zedoaria ${ }^{* *}$ Ex & & & \\
\hline
\end{tabular}




\begin{tabular}{|c|c|c|c|c|}
\hline & Hedychium coccineum ${ }^{* *} E x$ & & & \\
\hline & Hedychium flavescens ${ }^{* *} E x$ & & & \\
\hline & Zingiber cylindricum ${ }^{* * E n}$ & & & \\
\hline & Zingiber officinale $^{* * E x}$ & & & \\
\hline & Zingiber wightianum $^{* * I n}$ & & & \\
\hline & Zingiber zerumbet ${ }^{*} E x$ & & & \\
\hline & Unidentified sp. & & & \\
\hline $\begin{array}{l}\text { Notocrypta curvifascia } \\
\text { curvifascia }\end{array}$ & Zingiber zerumbet ${ }^{* *} E x$ & Zingiberaceae & $\mathrm{L}$ & \\
\hline Hyarotis adrastus adrastus & Calamus rotang ${ }^{* * I n}$ & Arecaceae & $\mathrm{L}$ & \\
\hline & Bambusa vulgaris ${ }^{* *}$ In & & & \\
\hline Matapa aria & Dendrocalamus giganteus ${ }^{* *} E x$ & Poaceae & $\mathrm{L}$ & \\
\hline & Ochlandra stridula ${ }^{* *} E n$ & & & \\
\hline Spialia galba & Sida acuta ${ }^{* * I n}$ & Malvaceae & $\operatorname{Im~L}$ & \\
\hline Taractrocera maevius & Axonopus compressus ${ }^{* *}$ Ex & Poaceae & $\mathrm{L}$ & \\
\hline Oriens ooloides & Setaria barbata ${ }^{*}{ }^{\prime n}$ & Poaceae & $\mathrm{L}$ & \\
\hline Oriens goiolaes & $\begin{array}{l}\text { Unidentified sp. } \\
\end{array}$ & Foacede & L & \\
\hline Potanthus confuscius satra & Unidentified sp. & Poaceae & $\mathrm{I}$ & \\
\hline Fotanthus conjusctus satra & Unidentified sp. & Foacede & $\mathrm{L}$ & \\
\hline Telicota colon kala & Unidentified sp. & Poaceae & $\mathrm{L}$ & \\
\hline & Bambusa multiplex ${ }^{* *} E x$ & & & \\
\hline & Bambusa ventricosa ${ }^{* * E x}$ & & & \\
\hline Telicota bambusae lanka & Bambusa vulgaris ${ }^{* * I n}$ & Poaceae & $\mathrm{L}$ & \\
\hline & Dendrocalamus giganteus ${ }^{* *} \mathrm{Ex}$ & & & \\
\hline & Ochlandra stridula ${ }^{* *} E n$ & & & \\
\hline & Cocos nucifera $^{*}{ }^{\prime \prime n}$ & & $\mathrm{~L}$ & \\
\hline Cephrenes trichopepla & Phoenix pusilla $^{* *}$ In & Arecaceae & $\mathrm{T}$ & \\
\hline & Saribus rotundifolius ${ }^{* *} E x$ & & $\mathrm{~L}$ & PC: v. Pootern \\
\hline Baoris penicillata & Ochlandra stridula ${ }^{* * E n}$ & Arecaceae & $\mathrm{L}$ & \\
\hline & Coix lacryma-jobi ${ }^{* * 1 n}$ & & & \\
\hline Borbo cinnara & Panicum maximum ${ }^{* * * x}$ & Poaceae & $\mathrm{L}$ & \\
\hline Borbo cinnara & Setaria barbata ${ }^{* * I n}$ & Poaceae & & \\
\hline & Zea mays $* *$ Ex & & & \\
\hline Pelopidas agna agna & Unidentified sp. & Poaceae & $\mathrm{L}$ & \\
\hline Pelopidas mathias mathias & Oryza sativa ${ }^{* * I n}$ & Poaceae & $\mathrm{L}$ & \\
\hline & Coix lacryma-jobi ${ }^{* * 1 n}$ & & & \\
\hline Pelopidas conjuncta narooa & Panicum maximum ${ }^{* *} E x$ & Poaceae & $\mathrm{L}$ & \\
\hline & Saccharum officinarum ${ }^{* *} E x$ & & & \\
\hline & Bambusa multiplex ${ }^{* *} E x$ & & $\mathrm{~L}$ & only in the lab \\
\hline Caltorls kumara lanka & Davidsea attenuata ${ }^{* * E n}$ & Poaceae & $\mathrm{L}$ & \\
\hline & Bambusa multiplex ${ }^{* * E x}$ & & & \\
\hline Caltoris nhilinning soriata & Bambusa vulgaris ${ }^{* * 1 n}$ & Рогесеге & $\mathrm{I}$ & \\
\hline Canoris pratiptina seriaia & Dendrocalamus giganteus ${ }^{*}$ Ex & ruacede & $\mathrm{L}$ & \\
\hline & Ochlandra stridula ${ }^{* *} E n$ & & & \\
\hline Parnara bada bada & 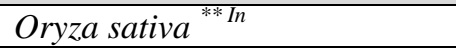 & Poaceae & $\mathrm{I}$ & \\
\hline Parnara baa baaa & Unidentified sp. & Poaceae & $\mathrm{L}$ & \\
\hline
\end{tabular}

Note: Plant parts cited in the plant column describe the components of the plant feed on by the larvae. If the larvae does not strictly adhere to a specific state of leaves it is broadly mentioned as "leaves". However, all larvae, especially the early instars, prefer immature leaves. If it is not specifically mentioned, all the plants were recorded in the field. Plants were considered as confirmed LFPs, if the larvae were successfully reared up to the adult stage. If an observation was restricted to egg laying by an adult butterfly, it was mentioned specially. These types of plants were included only if the plant is closely related to a known LFPs for that specific butterfly or if the adult butterfly searched the same plant to lay eggs. Still, no attempts were made to rear larvae on these plants and their use can only be confirmed by future studies.

*Editor's end note: The above list of plant names is based primarily on publications dealing specifically with the flora of Sri Lanka and does not take into account recent taxonomic and nomenclatural changes proposed over the last decade or so; see GRIN and The PLANT LIST for more up-to-date information. 


\section{PLATE 12}

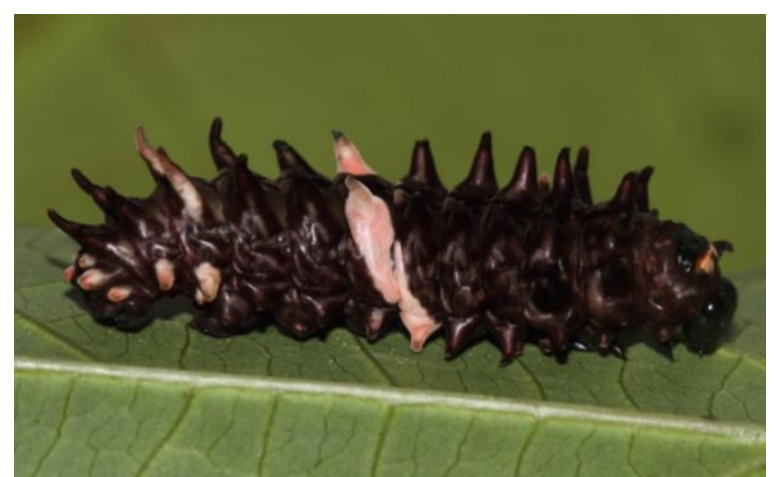

Figure 1: Sri Lankan bird wing (Troides darsius)

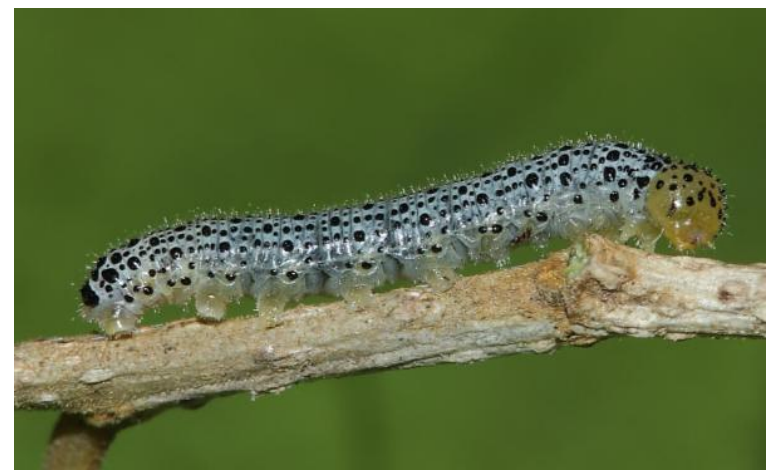

Figure 3: Sri Lankan lesser albatross (Appias galena)

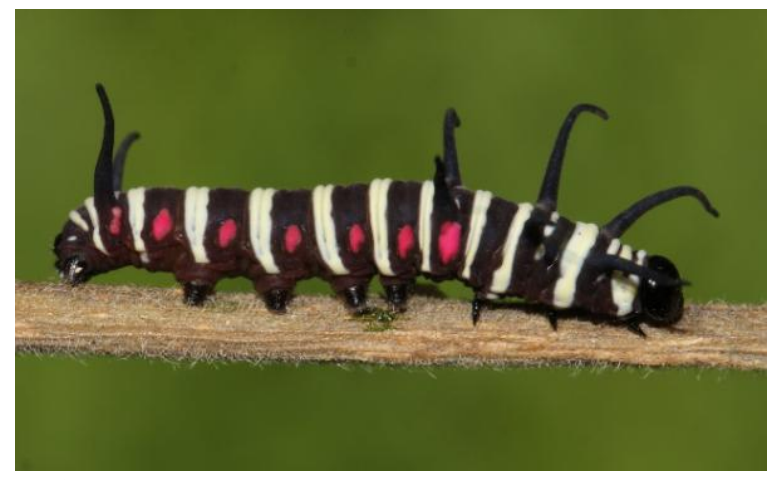

Figure 5: Sri Lankan tree nymph (Idea iasonia)

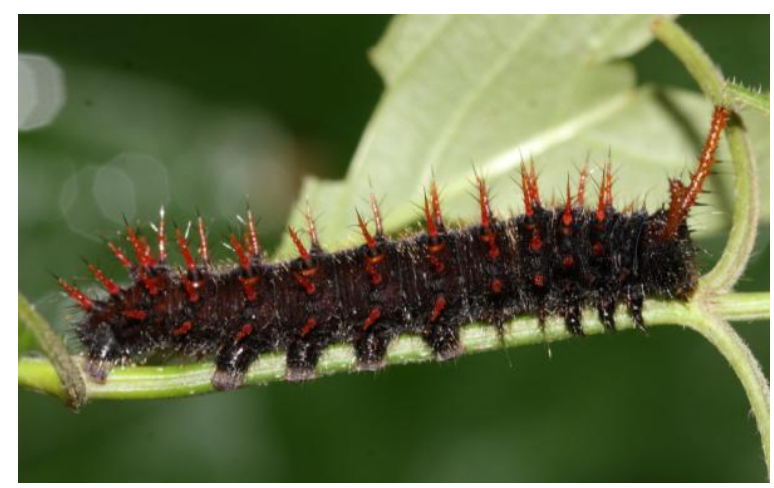

Figure 7: Sri Lankan blue oak leaf (Kallima philarchus)

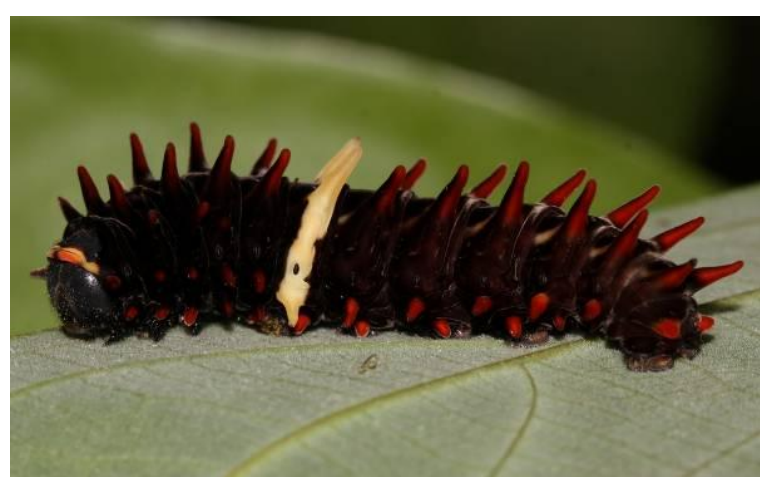

Figure 2: Sri Lankan rose (Pachliopta jophon)

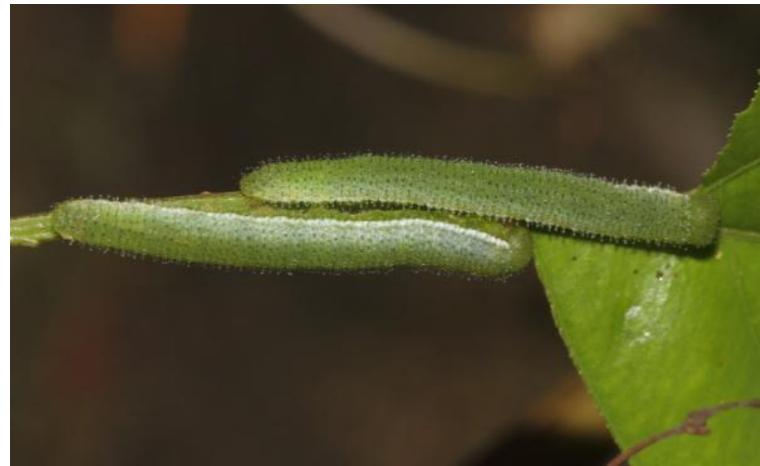

Figure 4: Sri Lankan one spot grass yellow (Eurema ormistoni)

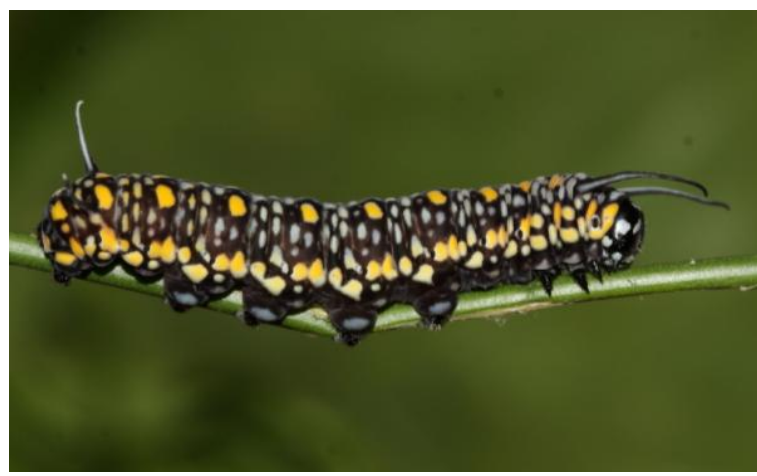

Figure 6: Sri Lankan tiger (Parantica taprobana)

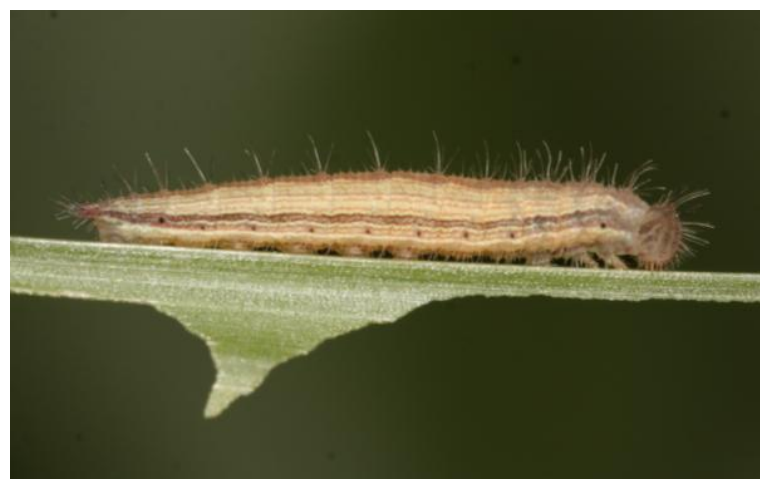

Figure 8: Sri Lankan jewel four ring (Ypthima singala) 


\section{PLATE 13}

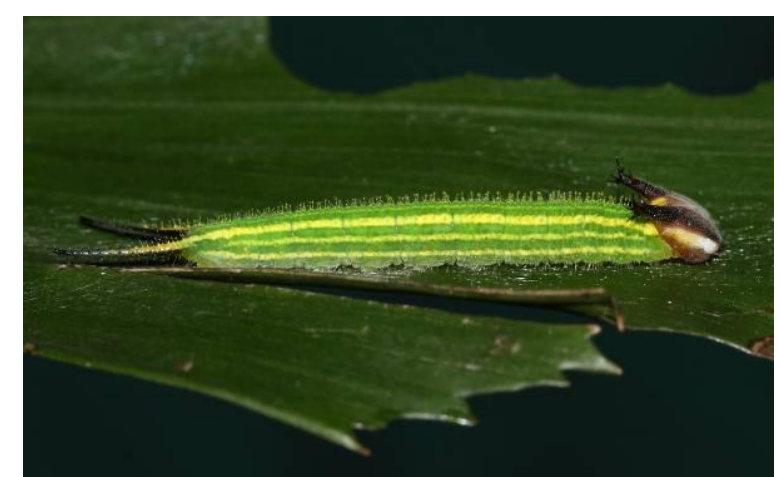

Figure 9: Sri Lankan palmfly (Elymnias singhala)

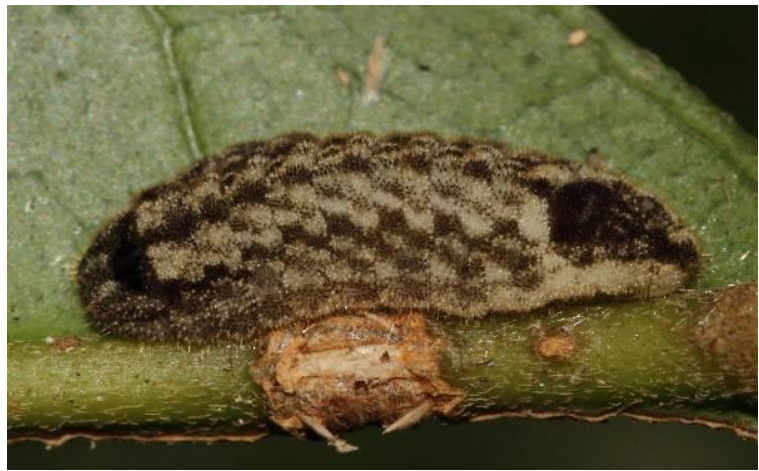

Figure 11: Sri Lankan milky cerulean (Jamides lacteata)

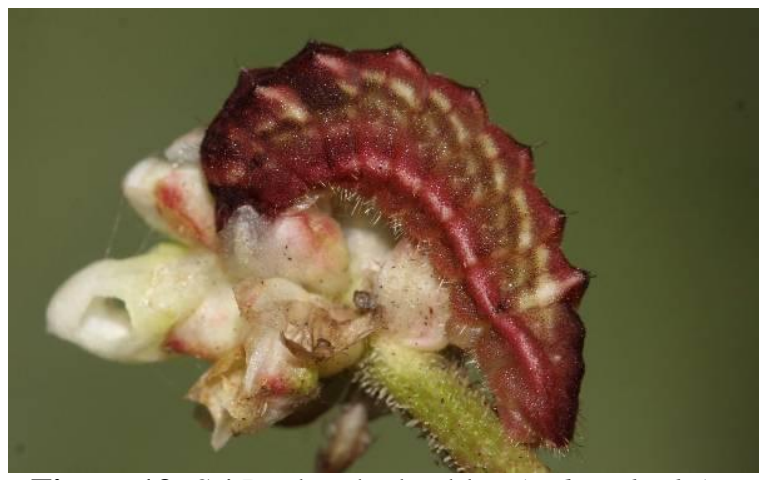

Figure 13: Sri Lankan hedge blue (Udara lanka)
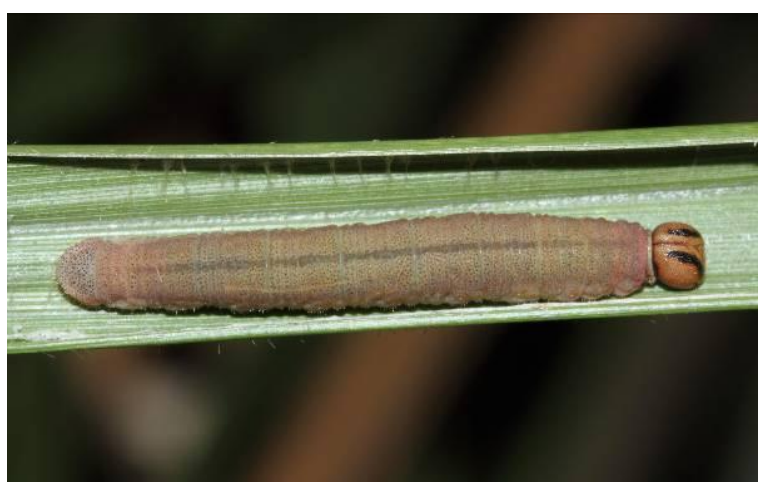

Figure 15: Sri Lankan hedge hopper (Baracus vittatus)

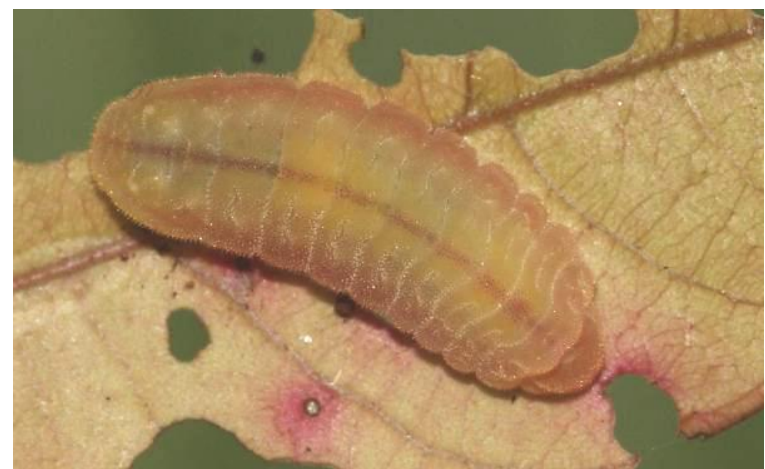

Figure 10: Sri Lankan pale six lineblue (Nacaduba sinhala)

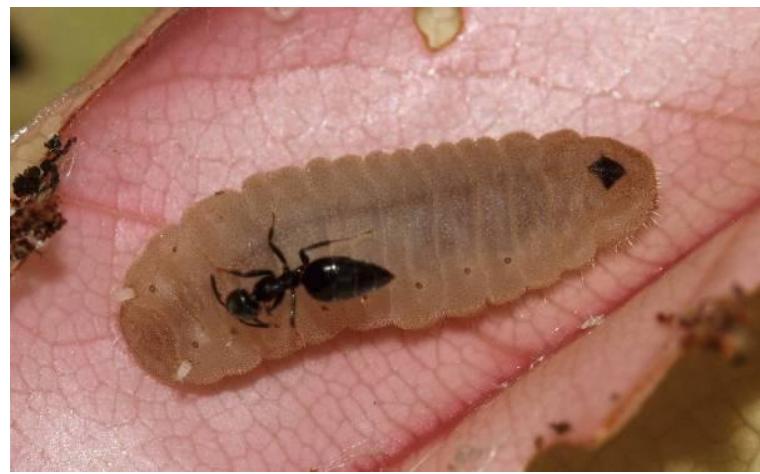

Figure 12: Sri Lankan cerulean (Jamides coruscans)

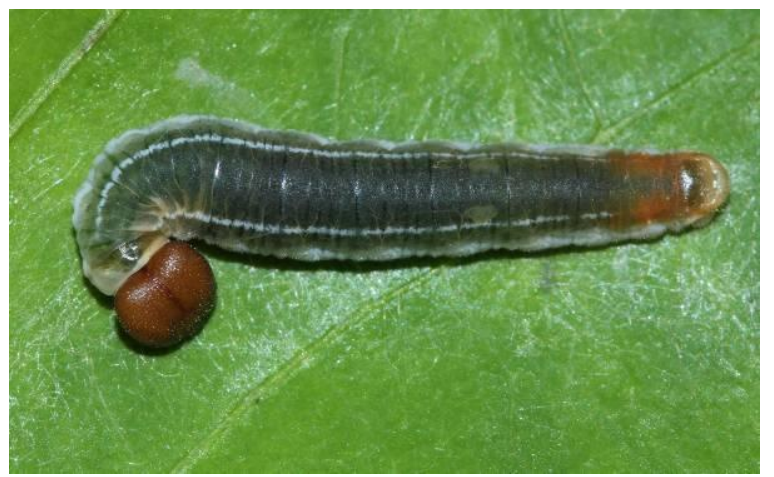

Figure 14: Sri Lankan black flat (Celaenorrhinus spilothyrus)

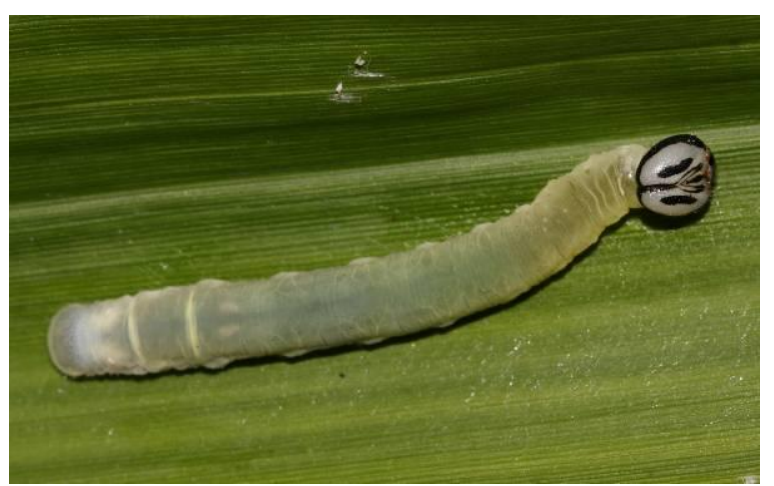

Figure 16: Sri Lankan paint brush swift (Baoris penicillata) 